\title{
Glucose Transporters in Cardiac Metabolism and Hypertrophy
}

\author{
Dan Shao ${ }^{1}$ and Rong Tian ${ }^{*} 1$ \\ ${ }^{1}$ Mitochondria and Metabolism Center, University of Washington, Seattle, Washington, USA
}

\section{Abstract}

The heart is adapted to utilize all classes of substrates to meet the high-energy demand, and it tightly regulates its substrate utilization in response to environmental changes. Although fatty acids are known as the predominant fuel for the adult heart at resting stage, the heart switches its substrate preference toward glucose during stress conditions such as ischemia and pathological hypertrophy. Notably, increasing evidence suggests that the loss of metabolic flexibility associated with increased reliance on glucose utilization contribute to the development of cardiac dysfunction. The changes in glucose metabolism in hypertrophied hearts include altered glucose transport and increased glycolysis. Despite the role of glucose as an energy source, changes in other nonenergy producing pathways related to glucose metabolism, such as hexosamine biosynthetic pathway and pentose phosphate pathway, are also observed in the diseased hearts. This article summarizes the current knowledge regarding the regulation of glucose transporter expression and translocation in the heart during physiological and pathological conditions. It also discusses the signaling mechanisms governing glucose uptake in cardiomyocytes, as well as the changes of cardiac glucose metabolism under disease conditions.

\section{Overview of Glucose Transporter}

Glucose is a vital metabolic fuel for all mammalian cells. Under physiological conditions, cell activities and survival are largely dependent on a continuous supply of blood-borne nutrients. The heart, which is adapted to contract constantly, is responsible for delivering oxygen, metabolic substrates as well as hormones to other parts of the body. To maintain its contractile function, the heart needs a continuous fuel supply for generation of adequate amount of ATP. Thus, the heart is adapted to utilize various metabolic substrates and is able to tightly control its substrate utilization in response to changes in substrate supply and/or circulating hormone levels. Fatty acid is considered to be the major metabolic substrate for the normal adult heart. Glucose and lactate account for about $25 \%$ to $30 \%$ of myocardial ATP production. Although glucose is not the predominant fuel for the adult heart at resting stage, the heart switches substrate preference from fatty acid to glucose at many circumstances during stress such as ischemia, increased workload and pressure overload induced hypertrophy.

The lipid bilayer of plasma membrane is impermeable for glucose due to its hydrophilic property; therefore, glucose uptake by the cell is mediated via a variety of glucose

“Correspondence to rongtian@uw.edu. 
transporters. The pattern of glucose transporter expression in different tissues is related to the specific metabolic requirements. There are two different types of transporters, the $\mathrm{Na}^{+}-$ coupled carrier system and the facilitative glucose transporters (GLUT) $(15,23)$. GLUT family proteins are the major players for glucose transport in the heart. The GLUT protein family belongs to the major facilitator superfamily of membrane transporters (169). In the 1970s, Kasahara et al. have described that glucose transport is mediated by a transmembrane protein in human erythrocytes (100). Later on, Mueckler et al. has predicted the structure of the facilitative glucose transporter, suggesting that the GLUT proteins comprise the twelve transmembrane domains and contain $\mathrm{N}$-terminus and $\mathrm{C}$-terminus cytoplasmic domains (160) (Fig. 1). The crystal structure of the glycerol-3-phosphate transporter of Escherichia coli, similar to GLUT family proteins, confirmed the proposed model of the GLUT proteins (118). Based upon that, a three-dimensional model of GLUT1 has been developed and binding of glucose and other substrates was predicted in close proximity to the exofacial vestibule in this model. And the classic GLUT inhibitor, cytochalasin B, has been docked only at one particular endofacial position of the protein (194) (Fig. 1). After decades of investigation, Dong et al. reported the crystal structure of human GLUT1 in 2014 (35). This structure allows accurate mapping and potential mechanistic interpretation of disease-associated mutations in GLUT1.

In 1985, cDNA of red blood cell glucose transporter (GLUT1) was first cloned (160). Later on, another 13 related members of GLUT protein family have subsequently been identified in human (230). The 14 known members of the GLUT family are summarized in Table 1. The human GLUT family can be divided into three subfamilies according to their sequence similarity and functional domains $(95,96)$. Most GLUT proteins catalyze the facilitative (energy-independent) bidirectional transfer of their substrates across membranes, but they exhibit tissue specific expression pattern and localization; furthermore, they have different functional characteristics such as substrate specificity, kinetics of transport and regulatory mechanism, which allows for a fine-tuned regulation of glucose uptake in response to cellular environment changes.

In the heart, the most abundant glucose transporters are GLUT1 and GLUT4. GLUT1 mainly localizes on plasma membrane, and is responsible for a significant component of basal cardiac glucose uptake. On the other hand, GLUT4 is mostly present in the intracellular vesicles at resting stages, and is translocated to the plasma membrane upon insulin stimulation. GLUT4-mediated glucose transport represents an important mechanism by which the net flux of glucose uptake by the cell can be tightly regulated by environmental changes. This review will summarize the current knowledge regarding the regulation of facilitative glucose transporter expression and translocation; the mechanisms involved in the regulation of glucose uptake into cardiomyocytes and discuss changes of glucose metabolism in pathological cardiac hypertrophy.

\section{Class I Facilitative Glucose Transporters}

The Class I transporters comprise the thoroughly characterized isoforms GLUT-1, $-2,-3$, and -4 , and the recently identified GLUT-14 (230, 256). GLUT1 is a ubiquitous transporter found on the plasma membrane in many tissues, including the heart, and accounts for the 
bulk of basal glucose uptake (161). The GLUT2 is a low-affinity glucose transporter with predominant expression in the liver, kidney, pancreas beta cell, and small intestine (159, 240). In addition to glucose, GLUT2 is also able to transport fructose and glucosamine (240, 256). GLUT3 is a high-affinity glucose transporter with predominant expression in the brain, which has a high glucose requirement but has also been reported in skeletal muscle and heart $(72,103)$. GLUT4 is a high-affinity glucose transporter expressed in insulinsensitive tissues (heart, skeletal muscle, and adipose tissue) $(61,221)$. Translocation of GLUT4 induced by insulin or other stimuli from intracellular storage vesicles to the plasma membrane results in an immediate 10 - to 20 -fold increase in glucose uptake $(21,211)$. The human gene encoding GLUT14 is exclusively expressed in testis and shares 95\% similarity with GLUT3 based upon amino acid sequence (257). There is no ortholog of GLUT14 found in mice.

\section{Class II Facilitative Glucose Transporters}

The class II facilitative glucose transporters include the fructose-specific transporter GLUT5, GLUT7, GLUT9, and GLUT11. GLUT5 is predominantly expressed in small intestine, testis, and kidney and is responsible for the uptake of fructose without glucose transport activity $(32,102)$. GLUT7 is a high-affinity transporter for glucose and fructose, which is predominately expressed at the apical membrane of the small and large intestine (124). Its expression can also be detected in colon, testis, and prostate. GLUT9 predominantly exists in liver and kidney. Less amount of GLUT9 are also found in small intestine, lung, placenta as well as leukocytes (174). Fructose, rather than glucose, is considered to be the major substrate for GLUT11. High expression of GLUT11 is detected in brain, liver, pancreas and kidney. And moderate expression of GLUT11 is observed in cardiac and skeletal muscle $(43,202)$.

\section{Class III Facilitative Glucose Transporters}

Class III comprises the transporter isoforms GLUT6, GLUT8, GLUT10, GLUT12, and HMIT. GLUT6 cDNA was originally cloned from leukocytes and is predominantly expressed in brain, spleen, and peripheral leukocytes. Overexpression of GLUT6 facilitates glucose uptake, indicating that GLUT6 has glucose transport activity, however, its physiological substrate has not been determined yet $(42,126)$. GLUT8 is predominantly expressed in brain and testis, and lower amounts of GLUT8 mRNA are detected in most other tissues, including insulin-sensitive tissues like heart and skeletal muscle (44). When expressed in Xenopus laevis oocytes, GLUT8 mediates glucose uptake with high affinity. Whether the transporter actually mediates glucose uptake in vivo in the brain has not been evaluated yet (22). GLUT10 is predominantly expressed in the liver and pancreas $(33,144)$. GLUT12 is predominantly expressed in heart and prostate and exhibits glucose transport activity when expressed in Xenopus laevis oocytes $(137,186)$. On the other hand, HMIT has been shown to be an $\mathrm{H}^{+}$-coupled myoinositol transporter, predominantly expressed in the brain (239). Many of the Class II and Class III isoforms in the GLUT family have been discovered only in recent years as a consequence of the sequencing of the human genome. Relatively little is known about the specific functions of these newly identified GLUTs. 


\section{Glucose Transporter in the Heart}

\section{The expression of glucose transporter in the heart}

The predominant glucose transporter isoforms that expressed in the heart are GLUT1 and GLUT4. Their expression is tightly regulated during development. Changes of each of these isoforms also occur during various pathophysiological states. Transcriptional regulation is the major mechanism that determines the expression and activity of these glucose transporters in the heart. Other members of the glucose transporter family have also been reported in the heart, including GLUT3, GLUT8, GLUT10, GLUT11, and GLUT12 with various expression level. GLUT3 has been found in both adult and fetal heart. Compared with GLUT1 and GLUT4, GLUT3 has a much higher affinity for hexose $(72,131)$. Although the sequence of GLUT8 shares 29\% identical to GLUT1, whether GLUT8 regulates glucose transport in the heart is still unknown. Studies of GLUT8 knockout mice suggested that GLUT8 had a role in regulating cardiac atrial activity $(146,203)$. In zebrafish embryos, knockdown of GLUT10 causes cardiac abnormalities with a reduced heart rate and blood flow (254), suggesting that GLUT10 is required for the development of cardiovascular system. Two splice variants have been described for GLUT11 (43). The long form of GLUT11 is only detected in liver, lung, trachea, and brain. On the other hand, the short form of GLUT11, with low-affinity glucose transport ability, is predominantly expressed in heart and skeletal muscle (43). The glucose transport ability of GLUT11 is inhibited by fructose, indicating that fructose maybe the major substrate for GLUT11 in the heart. It has been shown that insulin stimulation causes the translocation of GLUT12 to plasma membrane in both human skeletal muscle and cultured myoblast, similarly as the insulin-stimulated GLUT4 translocation (223). However, recent studies demonstrate that GLUT12 functions primarily as a basal and insulin independent glucose transporter in the heart (244). GLUT12 deficiency in zebrafish during early development shows sign of heart failure and diabetic phenotype (93). All those data suggest that GLUT12 plays an essential role for basal glucose uptake especially during development.

GLUT1-GLUT1 is the predominant glucose transporter in the embryonic and neonatal heart $(153,247)$. GLUT4 is rapidly upregulated after birth while GLUT1 is downregulated resulting that GLUT4 being the primary glucose transporter in the normal adult heart. The expression of GLUT1 is mainly determined by the activity of GLUT1 gene transcription. Sp1 and Sp3 are the most well-characterized transcriptional factors that regulate GLUT1 expression in the heart. Sp1 binds to the $-102 /-82$ region of the GLUT1 promoter to stimulate the transcription during late fetal life. Downregulation of Sp1 is observed during early neonatal life and minimal expression and/or DNA binding is found during adulthood (198). During myogenesis, Sp1 is drastically downregulated resulting in decreased GLUT1 expression and reduced glucose uptake (243). On the other hand, Sp3 is a repressor of GLUT1 expression in the heart. Sp3 binds to the GLUT1 proximal promoter region and inhibits the transcription of GLUT1 in muscle cells. It has been shown that the inhibitory effect of Sp3 is dominant over the stimulatory effect of Sp1 on the transcription of GLUT1 gene (53). The increased ratio of Sp3/Sp1 during myogenesis is essential for the decreased expression of GLUT1 (53). 
The expression of GLUT1 in the adult heart is regulated by multiple (patho)physiological stimuli. Chronic hypoxia has been shown to induce GLUT1 expression in the heart and the upregulation of GLUT1 appears to be protective by preventing cardiomyocytes apoptosis during hypoxia $(138,213)$. In other cell types, hypoxia-inducible factor-1a (HIF-1a) can directly bind to GLUT1 promoter $(25,260)$, suggesting that hypoxia induced GLUT1 upregulation is likely to be mediated by HIF-1a in the heart. Long-term fasting ( $48 \mathrm{~h}$ ) suppresses basal glucose uptake and induced downregulation of GLUT1 expression in the heart (108). However GLUT4 expression and insulin mediated glucose uptake dose not change after $48 \mathrm{~h}$ fasting, indicating that GLUT4 is the major mediator of insulin stimulated glucose uptake in the heart $(108,114)$. Maintenance of fed insulin levels during fasting prevents the downregulation of GLUT1. On the other hand, raising glucose or free fatty acids (FFAs) levels attenuates insulin induced GLUT1 upregulation, suggesting that both insulin exposure and energy status of cardiac muscle are important determinants of cardiac GLUT1 expression (114). Insulin receptor (IR) knockout mice show decreased GLUT1 level highlighting the importance of insulin in regulating cardiac GLUT1 expression (12).

It has been shown that the heterodimer of C-Fos and AP-1 regulates the transcription of GLUT1 in the heart in response to hypertrophic agonists (199). A decreased ratio of GLUT4/GLUT1 has been reported in patients with left ventricular hypertrophy (171). Similar observations are also made in animal models of pathological cardiac hypertrophy. Pressure overload increases total GLUT1 expression but decreases total GLUT4 expression and these changes are associated with increased distribution of both transporters to the plasma membrane (233). Meanwhile, basal glucose uptake is increased but insulin-mediated glucose uptake is similar in hypertrophied and control hearts (233). In neonatal cardiomyocytes, GLUT1 transcription is activated by hypertrophy stimuli such as alphaadrenergic agonist, which is partially mediated through the RAS-MAPK pathway (153). Interestingly, in another model of left ventricular hypertrophy created by aortic banding in neonatal rabbits, there is a reduced glucose uptake without any changes in the expression of GLUT1 or GLUT4 (227), suggesting that species difference may reflect diverse regulatory mechanisms on GLUTs expression. Furthermore, those experimental discrepancies may be dependent on the extent of cardiac hypertrophy (compensated hypertrophy or transitioned to heart failure). For example, transition from compensated remodeling to heart failure is associated with upregulation of GLUT1 in rats after myocardial infarction (187), while downregulation of GLUT1 and GLUT4 have been observed in end-stage failing human hearts (182). Upregulation of GLUT1 is also induced by myocardial ischemia. For example, myocardial ischemia increases GLUT1 mRNA and protein level in both ischemic and nonischemic regions of the heart in several animal studies $(20,55)$. Translocation of GLUT1 to the sarcolemma membrane is also observed in canine heart during regional ischemia (262). Increased GLUT1 expression is also observed in unloaded or denervated heart as well as in the heart with doxorubicin administration $(36,84,241)$. We will discuss the mechanisms for the ischemia/hypoxia-mediated changes in the expression or translocation of cardiac GLUTs later.

GLUT4-GLUT4 is expressed predominantly in the postnatal and adult heart. Several transcriptional factors have been demonstrated to regulate GLUT4 transcription. The 
promoter region containing $2.4 \mathrm{~kb}$ DNA segment at the $5^{\prime}$ end of the GLUT4 gene has been identified to be responsible for regulating endogenous GLUT4 expression as well as its response to fasting and refeeding in adipose tissue, skeletal muscle and cardiac muscle (129). Further characterizations show that this region contains a myocyte enhancer factor (MEF2) binding domain at -466 to -457 bp that is critical for GLUT4 expression in muscle tissue and for increased GLUT4 expression during skeletal muscle regeneration $(128,157)$. However, deletion of this region has no effect on exercise or denervation-induced upregualtion of GLUT4 in cardiac and skeletal muscle (236), suggesting that transcriptional regulation of GLUT4 may be mediated by different mechanisms in a tissue specific and/or stimulus specific manner. Meanwhile, in the similar region, thyroid hormone receptor and MyoD can form a complex with MEF2, which is required for transcriptional activation of GLUT4 in cardiac muscle (200). Overexpression of peroxisome proliferator-activated receptor gamma coactivator-1 (PGC-1) can induce GLUT4 mRNA by coactivating MEF2C in L6 muscle cells (147). In STZ-induced diabetes rat, loss of MEF2A function in muscle tissue is responsible for the down-regulation of GLUT4 gene expression (156). Furthermore, a selective loss of MEF2D expression is observed in adipose tissue without any significant effect on the MEF2A isoform. Overexpression of MEF2A in adipose tissue is not sufficient to prevent GLUT4 downregulation (156), suggesting a complex mode of GLUT4 regulation in a tissue specific manner. Another regulatory domain, so called Domain I, which is located in the region -742 to -712 relative to the initiation site for transcription of GLUT4 gene, acts together with the adjacent MEF2 binding site in regulating GLUT4 transcription (168). The Kruppel-like factor 15 (KLF15) is shown to regulate the insulin-sensitive glucose transporter GLUT4 by interacting with MEF2A (71). However, a GLUT4 promoter lacking of MEF2-binding site is still expressed in cardiac and skeletal muscle (236), suggesting that other regulatory mechanisms act cooperatively with MEF2 family to regulate cardiac GLUT4 expression.

GLUT4 expression is subjected to endocrine and metabolic regulation. Insulin depletion induces the down-regulation of GLUT4 in the heart. Lipid infusion decreases GLUT4 gene expression and reduces insulin-stimulated glucose uptake in the heart (242). Increasing cardiac FFA metabolism by overexpression PPAR-alpha in the heart leads to repression of GLUT4 protein and mRNA (57). Taken together, these data suggest that fatty acids can modulate GLUT4 gene expression in the heart. Thyroid hormone is another important regulator of GLUT4 expression and glucose utilization in the heart. T3 or T4 administration increases GLUT4 gene expression as well as insulin-mediated glucose uptake in neonatal or cultured cardiomyocyte $(24,70)$. Recent studies demonstrate that estrogen receptor, ERa has a positive effect on GLUT4 expression in muscle. ERa knockout mice have decreased GLUT4 mRNA level in skeletal muscles (8). On the other hand, treatment with ER $\beta$ agonist 2,3-bis(4-hydroxyphenyl)propionitrile causes downregulation of GLUT4 expression in skeletal muscle, suggesting that ER $\beta$ has a suppressive role in regulating GLUT4 level (8). Whether estrogen receptor signaling has an effect on regulating cardiac GLUTs expression has not been determined yet.

In most rodent models of diabetes (type 1 or type 2), consistent observations have demonstrated that the expression of GLUT4 is decreased in the heart, associated with the decline in glucose utilization in the heart $(13,64,98,267)$. Several interventions have been 
shown to reverse the decline in GLUT4 expression that occurs in diabetes. Exercise prevents the downregulation of GLUT4 in STZ rats $(76,167)$. Vanadyl sulfate or recombinant insulinlike growth factor-1 administration can also prevent the decline of GLUT4 protein and normalize blood glucose level in diabetic rats $(5,105)$. Treatment of diabetic rats with an angiotensin-1 (AT-1) receptor antagonist reverses the diabetes-induced decline in GLUT4 protein in the heart (82). The mechanism for the decreased expression of GLUT4 expression in the heart is still not clear yet. Loss of insulin signaling can partially explain the phenotype, since treatment with insulin can normalize GLUT4 expression in insulin deficient diabetic animals. However, treatment with insulin also normalizes hyperglycemia and other metabolic defects such as increased FFA and ketones in diabetes, which have been shown to regulate GLUTs transporter expression. It should be noted that some of the interventions that normalize the GLUT4 expression also normalize the blood glucose. As discussed earlier, GLUT4 expression level is correlated with blood glucose level.

Altogether, these observations suggest that the reduction in GLUT4 content in the heart of diabetic subjects might be a consequence of the systemic metabolic disturbances.

Extensive studies have been conducted to examine the changes of GLUT4 gene expression in the heart under various pathophysiological conditions. In hypertrophied hearts, GLUT4 mRNA and protein level are decreased resulting in the reduction of insulin-mediated glucose uptake. On the other hand, GLUT1 expression and basal glucose uptake are enhanced (170, 233). Similar observation is also made in patients with compensated LV hypertrophy (171). In both nondiabetic and diabetic failing hearts from human patients, the expression of GLUT4 is drastically suppressed $(180,181)$. In response to energetic stress in the heart such as exercise or ischemia, GLUT4 translocates from intracellular compartment to the plasma membrane accompanied by the increased glucose uptake $(214,262)$. Exercise training also leads to increases in skeletal muscle GLUT4 levels, which has been observed in humans and rodents $(31,185)$.

\section{Regulation of glucose transport in the heart}

The overall flux of glucose through the facilitative transporters is determined by the transmembrane glucose concentration gradient, the number of glucose transporter (regulated by expression), subcellular distribution (regulated by translocation) as well as the intrinsic activity of glucose transporters.

The intracellular glucose concentration is usually low since intracellular glucose is rapidly phosphorylated by hexokinase (HK) and metabolized, which creates an inward transmembrane concentration gradient driving the glucose entry the cells. Therefore, high extracellular glucose concentration drives glucose transport into cells, whereas low extracellular glucose concentration, for example, during ischemia or hypoglycemia, decreases glucose entry into the cells. Since GLUT1 and GLUT4 are the major glucose transporters in the heart, the overall expression of those transporters and their relative distribution on plasma membrane determine the rate of glucose transport in the heart. As we have discussed above, the most important regulatory mechanism in controlling intracellular glucose transporter content depends upon the rate of transcription. GLUTs expression changes in different developmental stages. The transcriptional regulation of GLUTs is also 
regulated by various pathological stimuli, which occurs relatively slowly, considered as a long-term regulation of glucose transport. On the other hand, in response to acute ischemic or insulin stimulation, the primary mechanism for regulating glucose transport is the redistribution of glucose transporters from cytosolic storage pool to the plasma membrane, so called translocation (29). To some extent, the glucose transporter translocation also reflects a decrease in the rate of endocytosis or recycling of glucose transporters into the intracellular storage pool (201). Glucose transport is also regulated by posttranslational modification of glucose transporter proteins. In adipocytes, GLUT4 can be phosphorylated at its C-terminal end in response to catecholamine stimulation. This phosphorylation does not affect GLUT4 translocation to plasma membrane, but is associated with decreases glucose uptake $(91,113)$. Inhibition of mitogen-activated protein kinase decreases insulin stimulated glucose uptake without influencing GLUT4 translocation (225). These data suggest that GLUT4 activity can be regulated by phosphorylation dependent mechanism(s).

\section{Molecular mechanisms mediating glucose transporter translocation}

Several stimuli including insulin, ischemia, exercise, and catecholamine have been well documented to mediate GLUTs translocation in the heart. Similar to adipose tissue and skeletal muscle, the translocation of GLUT4 transporters accounts for the majority of the transarcolemmal transport of glucose in cardiomyocytes. Under nonstimulated conditions, majority of GLUT4 stays within intracellular storage vehicles. These membrane vehicles are considered to be a specialized subcompartment of the post-Golgi network (59). Two distinct storage pools of GLUT4 transporters exist in cardiomyocytes. The first pool contains predominantly GLUT4. And the second pool, which contains less amount of GLUT4 with enriched GLUT1 and secretory carrier membrane proteins, is considered a part of endosomal compartment (59). Functionally, insulin stimulates GLUT4 translocation in both populations of GLUT4. On the other hand, insulin withdrawal leads to reentry of GLUT1 and GLUT4 transporters to the respective pools from which they were translocated $(11,45,59)$. In normal conditions, GLUT4 does not permanently stays in the intracellular membrane vehicles, but continuously recycles with plasma membrane at very low rates.

Insulin signaling-Insulin so far is the most well-characterized stimulus that mediates GLUT4 translocation (Fig. 2). A substantial amount of work has been performed to dissect insulin mediated GLUT4 translocation in adipocytes, which turns out to be similar in the heart. The binding of insulin to IR activates the tyrosine kinase activity of the receptor, which leads to the autophosphorylation of IR. The activated IR subsequently binds to and phosphorylates a series of substrates including the insulin receptor substrate family proteins (IRS1-4) and the Cbl $(16,17)$. In skeletal and cardiac muscle, IRS1 binds to the regulatory subunit p85 of phosphoinositide 3-kinase (PI3K) and recruits PI3K to the plasma membrane, which leads to its activation. The PI3K is considered to be a major player for mediating insulin-induced glucose uptake (115). In the heart, PI3K appears to be necessary for GLUT4 translocation, since PI3K inhibitor blocked insulin stimulated GLUT4 translocation (49). Activation of $\mathrm{Cbl}$ is responsible for insulin-mediated glucose uptake through PI3K independent mechanism in adipocytes. However, whether this particular pathway is also operative in cardiac muscle is still under debate. Upon PI3K activation, the catalytic p110 subunit of PI3K catalyzes the phosphorylation of phosphoinositides to 
phosphatidylinositol-3,4,5-triphosphate, which in turn recruits and activates another kinase, phosphoinositide-dependent protein kinase 1 (PDK1) in the vicinity of the plasma membrane. Subsequently, PDK1 phosphorylates PKB/Akt and the two atypical protein kinase $\mathrm{C}(\mathrm{aPKC})$ isoforms, $\mathrm{PKC} \lambda$, and $\mathrm{PKC} \zeta$, which contribute in parallel to insulin-induced GLUT4 translocation (155).

There are three different isoforms of Akt including Akt1, -2 , and -3. Akt1 is responsible for mediating cardiomyocyte growth (34). On the other hand, Akt2 mainly mediates the metabolic effects of insulin (6). Upon activation, Akt phosphorylates the Akt substrate of $160 \mathrm{kDa}$ (AS160) and inhibits its activity. AS160 (also known as TBC1D4) has recently been identified as a substrate of Akt2 as well $(99,197)$. As a negative regulator of GLUT4 translocation, AS160 restrains GLUT4 in its intracellular membrane compartment in the basal stage (112). The insulin-induced phosphorylation of AS160 inhibits its activity and promotes its dissociation from GLUT4-containing vesicles, an essential step for the fusion between GLUT4 containing vehicles and plasma membrane (112) (Fig. 2). Therefore, inhibition of AS160 is required for GLUT4 translocation to the plasma membrane in the presence of insulin. AS160, exhibiting constitutive GTPase-activating activity, is a negative regulator of Rab GTPase. When interacting with AS160, Rab GTPase stays in the inactive, guanosine diphosphate-bound form (148). Phosphorylation of AS160 inactivates its GTPase-activating function and thereby enables the activation of Rab proteins. Several Rab proteins including Rab8a, Rab10, and Rab14 have been shown to be involved in insulinmediated GLUT4 translocation in adipocytes $(87,196)$. Other Rab proteins, Rab4a and Rab11a, which are not the substrates of AS160, also participate in GLUT4 vesicles trafficking in cardiomyocytes $(47,238)$.

Another parallel pathway that has been suggested to contribute to insulin-stimulated glucose uptake is the atypical PKCs, although they are much less characterized (Fig. 2). In response to insulin stimulation, PDK1 phosphorylates and activates two different aPKC isoforms, $\lambda$ and $\zeta$. This process also contributes to the insulin-induced translocation of GLUT4 and increases glucose uptake in adipocytes and skeletal muscle $(7,107,217)$. In PKC $\lambda$-knockout heart, insulin-stimulated glucose uptake is markedly reduced (54). The activity of $\mathrm{PKC} \zeta$ is required for insulin mediated GLUT4 translocation, although insulin does not further increase its activity in the heart (132). Therefore, $\mathrm{PKC} \zeta$ seems to play a permissive rather than a stimulatory role in insulin-mediated glucose uptake in cardiomyocytes (132). However, some observations show either no significant role or even a negative regulatory role of aPKC on glucose transport $(222,237)$. Therefore, whether atypical PKCs play a role in insulin-stimulated glucose uptake is not definitive yet.

Another IR-mediated glucose transport is mediated by Cbl through PI3K independent pathway (Fig. 2). This regulation has been well characterized in adipocytes. Upon insulin stimulation, Cbl-associated protein (CAP) interacts with Cbl. The adaptor protein APS helps the Cbl-CAP complex to be recruited to the IR. Upon phosphorylation of Cbl, the Cbl-CAP complex dissociates from the IR and translocates to lipid rafts. This step appears to be essential for glucose transport in response to insulin $(2,9,127)$. In vivo, Cbl-deficient mice display a decrease in adiposity and an improved peripheral insulin action (151). However, in vitro study demonstrates that knocking down of $\mathrm{Cbl}$ in adipocytes has no effect on insulin- 
stimulated glucose uptake or GLUT4 translocation (149), suggesting that $\mathrm{Cbl}$ is not required for insulin mediated glucose transport. Therefore, the importance of the CAP/Cbl pathway for insulin action on glucose transport is still not clear yet. In skeletal muscle, Cbl seems to be not involved in regulating insulin-mediated glucose uptake (151). In cardiomyocytes, the effect of $\mathrm{Cbl}$ on insulin signaling is less investigated.

As discussed above, the stimulatory effect of insulin on glucose transport involves a series of cellular events. Dysregulation of any of these signaling events could disturb insulin responsiveness and leads to insulin resistance. It is unlikely that relatively modest reduction of GLUT4 expression significantly contributes to insulin resistance in the heart $(39,40$, 212). Evidence indicates, however, that insulin resistance in the heart results from defects in GLUT4 vesicle translocation rather than changes in GLUT4 gene expression.

Ischemia and exercise-Ischemia and exercise also stimulate GLUTs translocation in skeletal and cardiac muscle. Similar to skeletal muscle, GLUTs translocation is induced by no flow as well as low flow ischemia, associated with enhanced glucose uptake in the heart $(152,262)$. Although both involve increased translocation of GLUTs, mechanisms responsible for ischemia or exercise-mediated glucose uptake appear to be distinct from that stimulated by insulin. Wortmannin, the inhibitor of PI3K can block insulin stimulated glucose transport but failed to block the translocation of GLUTs in response to myocardial ischemia or skeletal muscle contraction $(49,134)$. Later studies demonstrate that AMPactivated protein kinase (AMPK) is likely a mediator of this response. AMPK, an "energy gauge" of the cell, is activated in response to an increase in the AMP/ATP ratio during myocardial ischemia and exercise $(110,255)$. Administration of 5-aminoimidazole-4carboxamide-1-beta-3-ribofuranoside, an activator of AMPK, is sufficient to induce GLUT4 translocation and increase glucose transport through PI3K-independent pathways (190). Exercise can also increase AMPK activity and stimulate GLUT4 translocation to the plasma membrane in the heart (28), implicating AMPK as a mediator of this effect.

Inhibition of AMPK abolished hypoxia induced GLUTs translocation and glucose uptake (190). Transgenic mice with dominant negative AMPK demonstrate impaired GLUTs translocation, reduced glucose uptake following ischemia and are more susceptible to ischemic injury $(191,258)$. AS160 phosphorylation followed by AMPK activation is important for regulating GLUT4 traffic in skeletal muscle $(109,229)$. Nitric oxide (NO) production is also involved in AMPK mediated GLUT4 translocation in cardiomyocyte (123). Interestingly, NO production mediated by nitric oxide synthase (NOS) activation is required for insulin-mediated glucose uptake in adipocyte and skeletal muscle (188). In another study conducted in adipocyte, NO donors can stimulate glucose transport and GLUT4 translocation through insulin independent mechanism (228). Since both Akt and AMPK can phosphorylate eNOS and regulate its activity, NO becomes an important element in the cross-talk between insulin signaling and AMPK signaling for the regulation of GLUTs translocation. Mice with genetic disruption of both the eNOS and the nNOS exhibit insulin resistance (210), highlighting an essential role of NO in the translocation of GLUT4. However, the signaling mechanism downstream of NO for the GLUT4 translocation remains to be defined. 
Contraction and increased workload-Catecholamines can increase glucose uptake and the translocation of GLUT1 and GLUT4 in perfused heart, thus may play a role in mediating GLUTs translocation during exercise and ischemia $(50,179)$. In isolated cardiomyocytes, both alpha and beta-adrenergic stimulation lead to increases in glucose uptake, independent of changes in contraction (58). Wortmannin, the PI3K inhibitor can block the activation of glucose transport induced by alpha-adrenergic stimulation (46), but beta-adrenergic stimulation of glucose uptake seems to be independent of PI3K activation.

In contracting hearts, increasing workload is associated with increased glucose transporter translocation and enhanced glucose uptake $(179,253)$. Since calcium is an essential player for mediating cardiomyocyte contraction, it is reasoned that calcium may mediate glucose transport in cardiomyocytes. Previous studies have observed no effect or minor effects of calcium on glucose transport in cardiomyocytes $(18,26)$. A recent study, however demonstrates that in neonatal cardiomyocytes blocking calcium response in the presence of insulin is sufficient to reduce insulin-stimulated glucose uptake and to prevent GLUT4 translocation, suggesting that the effect of insulin on glucose transport can be partially mediated by calcium (27). On the other hand, calcium is not required for 2,4-dinitrophenol mediated GLUT4 translocation (172), indicating that calcium is not required for metabolic stress mediated glucose transport.

In skeletal muscle, activation of AMPK has been shown to regulate GLUTs translocation during muscle contraction. Similarly, activation of AMPK has been proposed to mediate the effect of increased workload induced GLUT4 translocation in the heart (28). However, some studies find no activation of AMPK in response to increased workload either in isolated perfused hearts or in intact hearts in vivo $(10,270)$. Instead, PI3K-dependent mechanism seems to be responsible for the increased glucose uptake in response to increased workload (10). Therefore, whether AMPK is activated by increased workload in the heart and whether AMPK is required for mediating the increased glucose uptake in this condition remains controversial so far. In AMPKa2 knockout mice, contraction-induced glucose uptake is only partially prevented, although AMPK activation is markedly reduced (133), indicating that there is another parallel signaling pathway leading to GLUT4 translocation in response to contraction. Protein kinase D (PKD; also known as novel PKC isoform $\mu$ ) is activated by contraction. Stimulation of glucose uptake and induction of GLUT4 translocation in cardiomyocytes by contraction were inhibited by the PKD inhibitors staurosporin and calphostin-C (133). Another study later demonstrates that in cardiomyocytes, production of reactive oxygen species by contraction activates PKD, which promotes GLUT4 translocation, separately from AMPK signaling (41).

\section{Mouse Models with Genetically Modified Glucose Transporters Transgenic mice with overexpression of GLUTs in the heart}

Overexpression of the human GLUT1 gene has been shown to increase glucose uptake, glycolysis, and increased storage of glycogen in both skeletal and cardiac muscle $(73,125)$. Cardiac-specific overexpression of GLUT1 (GLUT1-TG) does not alter systemic metabolism but protects the heart from developing heart failure in pressure overload induced hypertrophy model as well as prevents ischemic injury $(125,135)$. Contrary to the 
observations in cell culture, GLUT1-TG adapt to long-term increases in basal glucose uptake without the development of glucotoxicity in aging animals. However, chronic increases in myocardial glucose uptake and utilization reduces the metabolic flexibility and renders the heart susceptible to contractile dysfunction in high fat diet induced obesity (259). Another study using an inducible overexpression model shows that short-term cardiac specific induction of GLUT1 at the onset of pressure overload preserves mitochondrial function and attenuates pathological remodeling, but exacerbates the hypertrophic phenotype and is insufficient to prevent pressure overload-induced cardiac contractile dysfunction (173).

Transgenic mice with overexpression of human GLUT4 demonstrate increased rates of glucose uptake, glycolysis and glycogen in both skeletal and cardiac muscle in the absence of insulin $(14,77)$. The GLUT4-TG hearts do not further increase glycolysis in response to insulin stimulation using langendorff perfusion system (14). But insulin administration further increases glycogen content and glucose oxidation in GLUT4-TG mice, indicating that glycolysis is already maximal in GLUT4-TG hearts but glucose entry in response to insulin contributes to glycogen storage and enhanced glucose oxidation (14). As described earlier, dysregulation of glucose transporter has been found in several diabetes models, which raises the question whether overexpression of glucose transporter can improve glucose homeostasis and rescue diabetic phenotype. Selective overexpression of GLUT4 in skeletal and cardiac muscle significantly improves whole body insulin action and loweres the blood glucose level in streptozotocin-induced diabetic mice (121). Low-level tissuespecific (heart, skeletal muscle, and adipose tissue) expression of the GLUT4 minigene in transgenic mice improves glycemic control but not obesity, during high-fat diet feeding, suggesting a possible target for intervention in the treatment of type 2 diabetes (86). Similarly, overexpression of GLUT4 in $\mathrm{d} b / \mathrm{d} b$ diabetic mice demonstrates beneficial effects in preventing the development of diabetes and maintaining normal cardiac function $(13,66)$. Collectively, these studies suggest that increased glucose uptake by overexpression of glucose transporters can maintain whole body glucose homeostasis, correct metabolic changes systematically, and prevent diabetic cardiomyopathy.

\section{Mutant Mice Deficient of GLUTs}

Homozygous loss of GLUT1 is associated with embryonic lethality while GLUT1 heterozygous knockout animals show normal development and growth but with severe brain dysfunction $(80,248)$. Mouse embryos with overexpression of GLUT1 antisense construct are associated with growth retardation and developmental malformations, leading to small embryo weight (80). The heart, brain, and kidneys of the GLUT1-deficient embryos exhibit reduced GLUT1 expression and decreased glucose uptake, which is associated with enhanced apoptosis (80). These data suggest that GLUT1-mediated glucose uptake is critical for organ formation during developmental stage.

GLUT4-null mice, which lack of GLUT4 in muscle and adipocytes, are viable after birth (101). They exhibit growth-retarded phenotype and shorter life span associated with cardiac hypertrophy and dysfunction as well as severely reduced fat mass (101). Surprisingly, GLUT4 knockout mice are normoglycemic with insulin resistance and hyperinsulinemia in 
the fed state, indicating that GLUT4 is not required for maintaining basal blood glucose homeostasis. However, lacking GLUT4 causes severe defect on cellular glucose and fatty acid metabolism as well as cell growth (101). GLUT4-null mice have increased GLUT1 and GLUT2 expression in liver and heart, as a potential compensatory mechanism, but interestingly there is no upregulation of any known facilitative glucose transporter in skeletal muscle $(101,192)$. The mechanism by which homozygote GLUT4-null mice do not develop diabetes is still unclear. Current hypothesis is that genetic deletion of GLUT4 may increase the intrinsic activity and/or enhanced the translocation of existing glucose transporters (GLUT1 and/or unknown GLUTs). In contrast, heterozygous GLUT4 null mice develop hyperglycemia and hyperinsulinemia associated with reduced muscle glucose uptake, hypertension, and morphological alterations in heart and liver (220). Heterozygous GLUT4 knockout mice also develop diabetes around 6 months of age. Cardiomyopathy observed in these mice may be a consequence of hypertension and diabetes. Selective overexpression of GLUT4 in skeletal muscle is sufficient to prevent the development of diabetic phenotype in heterozygous GLUT4 knockout mice, suggesting that glucose uptake in skeletal muscle is essential for maintaining the whole body glucose homeostasis (235).

Although homozygous and heterozygous GLUT4 knockout mice develop cardiac dysfunction under unstressed condition, cardiac specific deletion of GLUT4 does not affect cardiac function under basal conditions or the overall life span $(1,232)$. However, deletion of GLUT4 in the heart causes a moderate hypertrophy even though the systemic metabolism is unaffected in this model. Furthermore, in contrast to decreased energy reserve status in most cases of pathological hypertrophy, a higher level of cardiac creatine phosphate was found in both cardiac specific or systematic GLUT4 deletion mice $(232,251)$. Basal glucose uptake was enhanced and increased glycogen content was observed in cardiac specific GLUT4 knock out mice, partially mediated by an upregulation of GLUT1 $(1,232)$. Up to 20 $\mathrm{h}$ fasting eliminated this compensatory mechanism, which leads to impaired glycolysis and insufficient ATP production in cardiac specific GLUT4 knockout mice during low flow ischemia (232). Taken together, these data suggest that GLUT4-mediated glucose transport represents an important mechanism by which the heart regulates energy metabolism and growth. This mechanism also plays a critical role for myocardial protection against ischemia and reperfusion injury (232).

The phenotypes of mouse models with genetically modified GLUTs are summarized in Table 2.

\section{Glucose Metabolism in the Heart}

When glucose enters the cell, it is rapidly phosphorylated and feed into multiple pathways (Fig. 3). Glucose phosphorylation by HK is the first regulatory step that drives glucose for further metabolism. When intracellular glucose is converted to glucose-6-phosphate (G-6-P), majority of it enters glycolytic pathway and eventually breakdown to pyruvate, which is further oxidized in the mitochondria. Besides glycolysis pathway, G-6-P is also a substrate for glycogen synthesis, ribose synthesis, the pentose phosphate pathway (PPP) and the aldose reductase (AR)/polyol pathway. When G-6-P is converted to fructose-6-phosphate (F-6-P), it can also enter the hexosamine biosynthetic pathway (HBP). Breakdown of 
glucose not only provides energy supply, also generates metabolic intermediates, which are essential for regulating cell growth and function. For example, glucose enters glucosamine pathway and regulates the activity of transcription factors by promoting their O-

GlcNAcylation (88). The glycolysis pathway is a major player in regulating cellular redox state, which affects the level of $\mathrm{NAD}^{+}$and modulates the activity of the $\mathrm{NAD}^{+}$-dependent enzymes such as Sirt1 deacetylase (264). Pyruvate oxidation contributes to the production of acetyl-CoA, which induces histone modifications, resulting in epigenetic control of gene expression (252). Moreover, cytosolic acetyl-CoA has been shown to play an important role in the regulation of starvation-induced autophagy (140).

In the adult heart, a small amount of G-6-P enters intracellular glycogen storage. The size of the cardiac glycogen pool is greater during the fetal and neonatal stages and glycogen content drops to about $2 \%$ of the myocyte volume in adulthood (37), which is much smaller than the glycogen content in the liver and skeletal muscle. Dynamic changes of the cardiac glycogen pool have been observed during physiological and pathological conditions. Increases in glucose entry, for example, hyperinsulinemia or reduced glucose utilization, for example, fasting or elevated FFAs in the blood lead to increased glycogen content $(158,205$, 218). Breakdown of glycogen provides a critical source of fuel during acute increases of cardiac work, for example, during adrenergic stimulation and intensive exercise, or during ischemia $(67,68,218)$.

The first step that commits glucose to the glycolytic pathway is mediated by phosphofructokinase-1 (PFK-1) (Fig. 3), which catalyzes the irreversible conversion of F-6$\mathrm{P}$ to fructose-1,6-bisphosphate (F-1,6-BP). The activity of PFK-1 is mainly modulated by allosteric regulation. AMP, ADP, and inorganic phosphate are the positive effectors for PFK-1, which accelerates glycolytic flux when ATP level drops. On the other hand, ATP, proton and fructose 1,6-bisphosphate can inhibit PFK-1 activity (166, 219). Citrate, generated by TCA cycle as well as long chain fatty acids is a negative regulator of PFK-1, thus, linking mitochondrial oxidative metabolism to glycolysis $(63,92)$. The most potent allosteric activator of PFK-1 is fructose-2,6-bisphosphate, which is synthesized from F-6-P through a reversible reaction catalyzed by phosphofructokinase-2 (PFK-2) $(85,154)$.

Fructose 2,6-bisphosphate can activate PFK-1 even in the presence of ATP by increasing the affinity of the enzyme for fructose 6-phosphate and by decreasing the inhibitory effects of ATP on PFK-1 (219). Conditions that stimulate glycolysis, such as insulin, adrenergic stimulation can increase the activity of PFK-2 $(166,219)$. Phosphorylation by AMPK causes PFK-2 activation, which serves as an essential mechanism to promote glycolysis in ischemia heart (143). PFK-2 is also allosterically inhibited by citrate, which decreases fructose-2,6bisphosphate level and further inhibits PFK-1 activity (154).

Another important regulator for glycolytic pathway is glyceraldehyde-3-phosphate dehydrogenase (GAPDH), which catalyzes the conversion of glyceraldehyde 3-phosphate (G-3-P) to 1,3-diphosphoglycerate (1,3-BPG) and NADH. Similarly as most dehydrogenases, GAPDH activity is inhibited by high level of NADH and proton (150).

Pyruvate kinase catalyzes the conversion from phosphoenolpyruvate to pyruvate and generates one molecule of ATP, another irreversible step of glycolysis in the heart (Fig. 3). 
Oxidation of pyruvate in the mitochondria completes the process of glucose oxidation. A highly regulated step in pyruvate oxidation is the irreversible conversion of pyruvate to acetyl coenzyme A (acetyl-coA) by pyruvate dehydrogenase (PDH) complex.

Phosphorylation of PDH by PDH kinase (PDK) inhibits its activity and it is reactivated by dephosphorylation. PDK is activated by elevated ratios of acetyl-CoA/free CoA or $\mathrm{NADH} / \mathrm{NAD}^{+}$and is inhibited by pyruvate $(37,139,219)$. If not oxidized via $\mathrm{PDH}$, pyruvate can form lactate via lactate dehydrogenase (LDH) reaction coupled with consumption of an electron from the NADH. This reaction is important for cellular redox state, especially under conditions of reduced oxidative metabolism. Alternatively pyruvate can be converted to oxaloacetate or malate catalyzed by pyruvate carboxylase or malic enzyme (ME). The socalled anaplerotic reaction contributes to maintain the pool size of TCA intermediates and TCA function in the heart (65). Pyruvate can also contribute to anaplerosis by transamination with glutamate to form alanine and the TCA cycle intermediate alphaketoglutarate $(38,65)$.

PPP provides an alternative fate for glycolytic intermediates. PPP contains the oxidative phase and the nonoxidative phase characterized by a series of enzymatic reactions (Fig. 3). Glucose-6-phosphate dehydrogenase (G6PD) is the rate-limiting enzyme that controls the entry of G-6-P into the PPP $(78,83)$. In oxidative phase of PPP, G6PD oxidizes G-6-P generated from the initial reaction of glycolysis to produce 6-phosphogluconolactone and one molecules of NADPH. In the nonoxidative phase, ribulose-5-phosphate may be used for nucleotide synthesis, especially important for cell proliferation and growth. It also can be used for aromatic amino acid synthesis or converted to F-6-P and glyceraldehydes-3phosphate through a series of aldolases and transketolases that reenter the pathway or are oxidized as fuel (78) (Fig. 3). NADPH generated from the oxidative PPP is used for maintaining the reduced glutathione level, an important element for cellular antioxidative defense (48). This reaction is generally considered beneficial, since deficiency of G6PD causes cells more susceptible to oxidative damage (56). The capacity of the oxidative PPP in the heart is limited as the basal activity of G6PD is very low (271). However, short-term treatment of $\mathrm{H}_{2} \mathrm{O}_{2}$ increased G6PD activity in adult cardiomyocyte and pharmacological inhibition of G6PD disrupted intracellular redox balance and subsequently impaired cardiac function in vitro and in vivo. Antioxidant treatment, but not by ribose supplementation rescued the functional impairments (89). Collectively, these observations suggest that G6PD is a critical component of the cellular antioxidant system in adult cardiomyocytes, and furthermore, that oxidative PPP plays an essential role in regulating cardiac function through maintaining the capacity of the antioxidant glutathione system.

Glucose metabolism also participates in intracellular signaling transduction through the HBP. F-6-P generated from the initial steps of glycolysis enters into HBP via glutamine F-6$\mathrm{P}$ aminotransferase (Fig. 3). The HBP produces uridine diphosphate- $N$-acetylglucosamine (UDP-GlcNAc), which serves as the monosaccharide donor for the $\beta$-O-linkage of $\mathrm{N}$ acetylglucosamine (O-GlcNAc) modification of proteins $(30,111)$. The posttranslational OGlcNAc of cellular proteins may cause functional changes, therefore, regulating key cellular processes. The dynamic change in O-GlcNAc modification is thought to be a stress response. Zachara et al. demonstrates that O-GlcNAc modification is activated under various 
stresses in multiple cell lines. Augmenting O-GlcNAc levels promotes cell survival, whereas depressing O-GlcNAc levels reduces survival, suggesting an essential role of O-GlcNAc modification in regulating cell survival $(249,266)$. Recently, O-GlcNAc has emerged as a key player in the primary pathophysiology of many cardiovascular diseases. The effect of OGlcNAc in cardiovascular system has been extensively reviewed $(30,111,141,265)$.

\section{Glucose Metabolism in Hypertrophied Heart}

It is well documented that hypertrophied hearts exhibit gene expression and metabolic profiles similar to that in fetal hearts, that is, increased reliance on glucose for fuel metabolism (180). Since glucose has a higher oxygen efficiency for ATP production, the shift of substrate preference from fatty acid to glucose is therefore considered beneficial in the hypertrophied and failing myocardium $(106,165)$. However, "glucotoxicity" is observed in cardiomyocytes cultured in high glucose medium $(183,224,234)$, raising concerns whether adult cardiomyocytes in hypertrophied hearts can tolerate enhanced glucose uptake. In transgenic mice overexpressing insulin-independent glucose transporter GLUT1 in the heart (GLUT1-TG), the hearts have adapted to long-term increases in glucose usage without developing dysfunction even in the old age (135). Moreover, the GLUT1-TG mice are protected from developing heart failure in pressure overload induced hypertrophy model as well as from ischemia/reperfusion injury $(125,135)$. Clinically, short-term treatment with CPT1 inhibitors, such as etomoxir and perhexiline, that increases glucose oxidation through reduction of fatty acid oxidation significantly improves cardiac function in heart failure patients $(116,204)$. These results suggest that promoting glucose utilization in the hypertrophied and failing heart could be beneficial. However, a short-term induction of GLUT1 in cardiomyocytes at the onset of pressure overload-induced hypertrophy failed to improve contractile function despite the beneficial effects on mitochondria function (173). Furthermore, the improvements in energetics and contractile function achieved by enhancing glucose uptake and utilization is not associated with any reduction of cardiac hypertrophy whereas preventing the shift of substrate preference to glucose decreases pathological hypertrophy during pressure overload $(104,125)$. These findings suggest that altered glucose metabolism in cardiac hypertrophy affects biological processes beyond energy generation. In this section, we will discuss in detail the changes of glucose metabolism in energy producing and nonenergy producing pathways in hypertrophied and failing hearts.

A major change of glucose metabolism during cardiac hypertrophy is accelerated glycolysis. Increased rate of glucose uptake and glycolysis has been reported in multiple animal models of cardiac hypertrophy $(97,162,233,268)$. Upregulations of GLUT1 expression have been observed in hypertrophied hearts both in vitro and in vivo $(153,233)$. Although the mRNA and protein levels of GLUT4 are decreased in hypertrophied hearts of both animal models and human patients, insulin stimulated glucose uptake is only moderately affected (170, 171, 233). It is likely that the increase of glycolytic flux in cardiac hypertrophy is largely dependent upon a higher rate of insulin-independent glucose uptake. It has been proposed that activation of AMPK in the hypertrophied heart, as the consequence of impaired energetics, is responsible for promoting GLUTs translocation, enhancing glucose uptake and stimulating glycolysis by phosphorylation/activation of PFK2 $(143,162,190,258)$. However, 
loss of function studies demonstrating the necessity of AMPK activation in mediating increased glycolysis in cardiac hypertrophy remains outstanding.

Besides alterations in GLUTs expression, no significant changes in expression or capacity of glycolytic enzymes have been observed in hypertrophied hearts. For example, the activities $\left(V_{\max }\right)$ of major glycolytic enzymes, including PFK, GAPDH, and LDH did not change in pressure overload induced hypertrophy (162). Increased reliance on glucose metabolism in hypertrophied hearts can be partially attributed to impaired fatty acid oxidation, which exerts a permissive effect on glucose utilization through Randle mechanism $(130,177,178)$. In cardiac hypertrophy and heart failure, downregualtion of genes involved in mitochondria biogenesis and oxidative metabolism, such as peroxisome proliferator-activated receptor alpha and PGC-1 and their targets, has been observed and proposed as an important causal mechanism for decreases in fatty acid oxidation under those conditions $(117,130,164,231)$. However, increased glycolysis in pathological hypertrophy is not accompanied by increased rate of glucose oxidation. Several studies have demonstrated that in hypertrophied hearts there is either no change or a decrease in the glucose oxidation $(4,51,245,246)$, suggesting an "uncoupling" of glycolysis and glucose oxidation in pathological hypertrophy. Since $\mathrm{PDH}$ is responsible for the oxidative decarboxylation of pyruvate to acetyl-CoA, one hypothesis is that defects in PDH activity are responsible for the "uncoupling." Surprisingly, hypertrophied hearts have normal protein expression of PDH and even have a slightly higher PDH activity compared with nonhypertrophied hearts (136). The activities of the kinase (PDK) and phosphatase that regulate PDH activities are not significantly changed in hypertrophied heart (136), thus, do not provide direct evidence supporting such a hypothesis.

Cytosolic pyruvate is transported into the mitochondria via a monocarboxylate acid/pyruvate carrier; hence, pyruvate carrier could be a potential mechanism for decreased glucose oxidation in hypertrophied hearts. However, the expression of the monocarboxylate transporter-1, facilitating the transport of lactate and pyruvate, increased substantially during heart failure (94). In isolated mitochondria from hypertrophied and nonhypertrophied hearts, pyruvate uptake is not found different and the maximal mitochondria oxygen consumption is similar in two groups when using pyruvate as a substrate (119). Collectively, those data suggest that pyruvate transport is not likely the player involved in the dysregulation of glucose oxidation in cardiac hypertrophy.

Increase in anaplerotic flux has been observed in hypertrophied hearts $(175,216)$. The majority of increased anaplerotic flux comes from malate adapted with elevated expression of ME (216). The elevated ME activity as well as the increased anaplerotic flux is considered to be an adaptive response for hypertrophied hearts to maintain normal TCA cycle flux. However, these metabolic shifts from the normal route of pyruvate oxidation lead to the reduced ATP production efficiency of carbohydrate (216). Whether anaplerosis participates in regulating cardiac hypertrophy is not determined yet.

If pyruvate cannot be oxidized, it can be converted to lactate through LDH. Although the LDH reaction is considered to be near equilibrium, reduced availability of pyruvate for oxidation might lead to exaggerated conversion of cytoplasmic pyruvate into lactate in cardiac hypertrophy due to the elevated LDH activity. Consistently shown in experimental 
and human hypertrophied hearts, increased activity of LDH has been documented (19, 60, $184,215)$. Several studies also observe that LDH isoform expression shifts toward the muscle-type subunit in hypertrophied hearts $(19,261)$, with elevated lactate production $(215$, 226). Although the production of lactate is increased in hypertrophied hearts, the overall rate of lactate oxidation is similar to nonhypertrophied hearts $(4,209)$. It is possible that there is reduced availability of pyruvate to oxidative metabolism in mitochondria due to the aberrant LDH activity in the hypertrophied heart.

Under aerobic conditions, NADH generated from glycolysis is transferred to mitochondria through the malate-aspartate shuttle and a-glycerophosphate shuttle and regenerates cytosolic NAD ${ }^{+}$in the heart $(189,193)$. Activation of the NADH shuttles has been identified in glycolytically active fetal hearts to adapt to high production of NADH in the cytosol (206, 207). The capacity of malate-aspartate shuttle, the major form of NADH shuttle in the heart, is dependent on oxoglutarate/malate carrier gene expression (207). However, no change in malate-aspartate or a-glycerophosphate shuttle capacity or the expression of its key components is found in hypertrophied hearts $(122,189)$.

In addition to glycolysis and pyruvate oxidation, multiple accessory pathways of glucose metabolism have also been altered in the hypertrophied myocardium. Glycogen metabolism not only contributes significantly to overall ATP production in normal aerobic hearts but also plays an essential role in energy metabolism when hearts are exposed to high workload or ischemia $(3,69,81,163)$. Both normal and pressure-overloaded hearts possess similar glycogen content at baseline. Myocardial ATP production contributed by glycogen metabolism is similar in hypertrophied hearts and nonhypertrophied hearts $(3,208)$. However, hypertrophied hearts preferentially oxidize glucose from glycogen stores as opposed to exogenous glucose compared to normal hearts (3). In response to ischemia, accelerated rates of glycolysis from exogenous glucose and increased rates of glycogenolysis have been observed in isolated hypertrophied hearts $(208,245)$. Glycogen turn over rate is higher in hypertrophied hearts compared with normal hearts during severe low flow ischemia (245). Despite this, the glycogen metabolism in the hypertrophied hearts is quite similar as the normal hearts.

Several studies observe an upregulation of PPP in hypertrophied heart $(145,272)$. The activity of G6PD, the rate-limiting enzyme of the PPP, is elevated in experimental hypertrophied models $(75,272)$. However, neither the expression of key enzymes involved PPP, nor the flux of PPP, are altered in the hearts under pressure overload $(120,263)$. Of note, G6PD-deficient mice are more vulnerable to ischemia reperfusion injury (90), highlighting the importance of PPP against oxidative stress. In response to long-term myocardial infarction or pressure overload, G6PD deficiency increased oxidative stress and exacerbated cardiac dysfunction in mice (79), further supporting the hypothesis that lack of NADPH production by G6PD deficiency reduces glutathione regeneration and disrupts redox balance in the heart. On the contrary, recent studies suggest that excessive NADPH derived from the oxidative PPP increase superoxide production and contributes to the development of heart failure $(74,75)$. In a desmin-related cardiomyopathy model, aberrant activation of G6PD contributes to the enhanced reductive stress and cardiac dysfunction (176). Thus, keeping the redox balance by G6PD reaction is essential for maintaining 
cardiac function. Either excessive production of NADPH (reductive stress) or insufficient production of NADPH (oxidative stress) via the G6PD reaction could be detrimental to the heart.

In models of pressure overload and age-related hypertrophy, UDP-GlcNAc concentrations and levels of key enzymes involved in HBP are greatly increased $(62,263)$. In db/db diabetic mice, activation of HBP and protein O-GlcNAcylation modulates hypertrophy signaling in cardiomyocytes (142). Collectively, those data suggest that HBP and/or O-GlcNAc is involved in the development of cardiac hypertrophy. Facundo et al. demonstrates that NFAT activation during cardiomyocyte hypertrophy requires O-GlcNAcylation (52), suggesting that cardiomyocyte hypertrophy may be driven by the direct O-GlcNAcylation of NFAT or other unknown hypertrophic signaling molecules. In infarction-induced heart failure model, increased O-GlcNAcylation and O-GlcNAc transferase (OGT) expression is observed in mice (250). Cardiac-specific deletion of OGT and consequent reduction in cardiac OGlcNAcylation significantly increase myocyte apoptosis and exacerbated cardiac dysfunction (250), suggesting that O-GlcNAcylation may mediate cell survival signaling during the development of heart failure.

Beside the posttranslational O-GlcNAcylation, emerging evidence suggested that accelerating glucose metabolism enhance production of cytosolic acetyl-CoA and regulate the acetylation of proteins in different cell types $(252,269)$. During induction of cardiac hypertrophy, the acetylation level of myosin heavy chain (MHC) isoforms is increased, providing a possible mechanism for modulating the motor activity of cardiac MHC isoforms in response to hypertrophy stimuli (195). The posttranslational modifications via glycosylation and acetylation in cardiac hypertrophy need more attention. Those modifications are largely regulated by cardiac metabolism and their changes reflect alteration of cardiac metabolism in response to various stimuli. Therefore, dissecting signaling events behind those modifications can help us to better understand the relationship between cardiac metabolism and pathogenesis of cardiac diseases.

\section{Conclusion}

In the past several decades, tremendous advances have been achieved in understanding different types of glucose transporters as well as the cellular and molecular mechanisms regulating glucose transport in the heart and other tissues. The mechanisms of GLUT4 translocation and consequent stimulation of glucose transport have been extensively studied in adipose tissue and skeletal muscles. It remains to be determined whether conclusions obtained from these two organs can be applied to the myocardium. Further investigations on the cardiac-specific regulatory mechanisms have the potential for developing pharmacologic or gene therapy capable of modulating glucose transport in the heart under disease conditions.

Prior research in animal models and patients has consistently demonstrated that heart with pathological hypertrophy is reprogrammed to a metabolic profile characterized by increased glycolysis and downregulation in fatty acid oxidation. However, the causes and consequences of these changes are not well understood. Thus, further elucidation of the 
molecular mechanisms underlying myocardial metabolic phenotype under normal physiological and disease conditions are warranted, and in particular, the regulatory roles of nonenergy producing pathways of substrate metabolism need more attention in the future studies.

\section{Acknowledgments}

This work was supported in part by U.S. National Institutes of Health Grants HL-088634, HL-110349, and HL-118989 (to R. Tian) and the American Heart Association Postdoctoral Fellowship 15POST21620006 (to D. Shao.)

\section{References}

1. Abel ED, Kaulbach HC, Tian R, Hopkins JC, Duffy J, Doetschman T, Minnemann T, Boers ME, Hadro E, Oberste-Berghaus C, Quist W, Lowell BB, Ingwall JS, Kahn BB. Cardiac hypertrophy with preserved contractile function after selective deletion of GLUT4 from the heart. J Clin Invest. 1999; 104:1703-1714. [PubMed: 10606624]

2. Ahn MY, Katsanakis KD, Bheda F, Pillay TS. Primary and essential role of the adaptor protein APS for recruitment of both $\mathrm{c}-\mathrm{Cbl}$ and its associated protein CAP in insulin signaling. J Biol Chem. 2004; 279:21526-21532. [PubMed: 15031295]

3. Allard MF, Henning SL, Wambolt RB, Granleese SR, English DR, Lopaschuk GD. Glycogen metabolism in the aerobic hypertrophied rat heart. Circulation. 1997; 96:676-682. [PubMed: 9244242]

4. Allard MF, Schonekess BO, Henning SL, English DR, Lopaschuk GD. Contribution of oxidativemetabolism and glycolysis to Atp production in hypertrophied hearts. Am J Physiol. 1994; 267:H742-H750. [PubMed: 8067430]

5. Asada T, Ogawa T, Iwai M, Kobayashi M. Effect of recombinant human insulin-like growth factor-I on expression of glucose transporters, GLUT 2 and GLUT 4, in streptozotocin-diabetic rat. Jpn J Pharmacol. 1998; 78:63-67. [PubMed: 9804063]

6. Bae SS, Cho H, Mu J, Birnbaum MJ. Isoform-specific regulation of insulin-dependent glucose uptake by Akt/protein kinase B. J Biol Chem. 2003; 278:49530-49536. [PubMed: 14522993]

7. Bandyopadhyay G, Standaert ML, Kikkawa U, Ono Y, Moscat J, Farese RV. Effects of transiently expressed atypical (zeta, lambda), conventional (alpha, beta) and novel (delta, epsilon) protein kinase $\mathrm{C}$ isoforms on insulin-stimulated translocation of epitope-tagged GLUT4 glucose transporters in rat adipocytes: specific interchangeable effects of protein kinases C-zeta and Clambda. Biochem J. 1999; 337(Pt 3):461-470. [PubMed: 9895289]

8. Barros RP, Machado UF, Warner M, Gustafsson JA. Muscle GLUT4 regulation by estrogen receptors ERbeta and ERalpha. Proc Natl Acad Sci U S A. 2006; 103:1605-1608. [PubMed: 16423895]

9. Baumann CA, Ribon V, Kanzaki M, Thurmond DC, Mora S, Shigematsu S, Bickel PE, Pessin JE, Saltiel AR. CAP defines a second signalling pathway required for insulin-stimulated glucose transport. Nature. 2000; 407:202-207. [PubMed: 11001060]

10. Beauloye C, Marsin AS, Bertrand L, Vanoverschelde JL, Rider MH, Hue L. The stimulation of heart glycolysis by increased workload does not require AMP-activated protein kinase but a wortmannin-sensitive mechanism. Febs Lett. 2002; 531:324-328. [PubMed: 12417335]

11. Becker C, Sevilla L, Tomas E, Palacin M, Zorzano A, Fischer Y. The endosomal compartment is an insulin-sensitive recruitment site for GLUT4 and GLUT1 glucose transporters in cardiac myocytes. Endocrinology. 2001; 142:5267-5276. [PubMed: 11713226]

12. Belke DD, Betuing S, Tuttle MJ, Graveleau C, Young ME, Pham M, Zhang D, Cooksey RC, McClain DA, Litwin SE, Taegtmeyer H, Severson D, Kahn CR, Abel ED. Insulin signaling coordinately regulates cardiac size, metabolism, and contractile protein isoform expression. J Clin Invest. 2002; 109:629-639. [PubMed: 11877471]

13. Belke DD, Larsen TS, Gibbs EM, Severson DL. Altered metabolism causes cardiac dysfunction in perfused hearts from diabetic (db/db) mice. Am J Physiol-Endoc M. 2000; 279:E1104-E1113. 
14. Belke DD, Larsen TS, Gibbs EM, Severson DL. Glucose metabolism in perfused mouse hearts overexpressing human GLUT-4 glucose transporter. Am J Physiol Endocrinol Metab. 2001; 280:E420-E427. [PubMed: 11171596]

15. Bell GI, Kayano T, Buse JB, Burant CF, Takeda J, Lin D, Fukumoto H, Seino S. Molecular biology of mammalian glucose transporters. Diabetes care. 1990; 13:198-208. [PubMed: 2407475]

16. Bertrand L, Horman S, Beauloye C, Vanoverschelde JL. Insulin signalling in the heart. Cardiovasc Res. 2008; 79:238-248. [PubMed: 18390897]

17. Bevan P. Insulin signalling. J Cell Sci. 2001; 114:1429-1430. [PubMed: 11282018]

18. Bihler I, McNevin SR, Sawh PC. Sarcolemmal glucose transport in Ca2+-tolerant myocytes from adult rat heart. Calcium dependence of insulin action. Biochim Biophys Acta. 1985; 844:9-18. [PubMed: 3881135]

19. Bishop SP, Altschuld RA. Increased glycolytic metabolism in cardiac hypertrophy and congestive failure. Am J Physiol. 1970; 218:153-159. [PubMed: 4243400]

20. Brosius FC, Liu YN, Nguyen N, Sun DQ, Bartlett J, Schwaiger M. Persistent myocardial ischemia increases GLUT1 glucose transporter expression in both ischemic and non ischemic heart regions. J Mol Cell Cardiol. 1997; 29:1675-1685. [PubMed: 9220353]

21. Bryant NJ, Govers R, James DE. Regulated transport of the glucose transporter glut4. Nat Rev Mol Cell Bio. 2002; 3:267-277. [PubMed: 11994746]

22. Carayannopoulos MO, Chi MMY, Cui Y, Pingsterhaus JM, McKnight RA, Mueckler M, Devaskar SU, Moley KH. GLUT8 is a glucose transporter responsible for insulin-stimulated glucose uptake in the blasto-cyst. P Natl Acad Sci USA. 2000; 97:7313-7318.

23. Carruthers A. Facilitated diffusion of glucose. Physiol Rev. 1990; 70:1135-1176. [PubMed: 2217557]

24. Castello A, Rodriguez-Manzaneque JC, Camps M, Perez-Castillo A, Testar X, Palacin M, Santos A, Zorzano A. Perinatal hypothyroidism impairs the normal transition of GLUT4 and GLUT1 glucose transporters from fetal to neonatal levels in heart and brown adipose tissue. Evidence for tissue-specific regulation of GLUT4 expression by thyroid hormone. J Biol Chem. 1994; 269:5905-5912. [PubMed: 8119934]

25. Chen CH, Pore N, Behrooz A, Ismail-Beigi F, Maity A. Regulation of glut1 mRNA by hypoxiainducible factor-1: Interaction between H-ras and hypoxia. J Biol Chem. 2001; 276:9519-9525. [PubMed: 11120745]

26. Cheung JY, Constantine JM, Bonventre JV. Cytosolic free calcium concentration and glucose transport in isolated cardiac myocytes. Am J Physiol. 1987; 252:C163-C172. [PubMed: 3103463]

27. Contreras-Ferrat AE, Toro B, Bravo R, Parra V, Vasquez C, Ibarra C, Mears D, Chiong M, Jaimovich E, Klip A, Lavandero S. An inositol 1,4,5-triphosphate (IP3)-IP3 receptor pathway is required for insulin-stimulated glucose transporter 4 translocation and glucose uptake in cardiomyocytes. Endocrinology. 2010; 151:4665-4677. [PubMed: 20685879]

28. Coven DL, Hu X, Cong L, Bergeron R, Shulman GI, Hardie DG, Young LH. Physiological role of AMP-activated protein kinase in the heart: graded activation during exercise. Am J Physiol Endocrinol Metab. 2003; 285:E629-E636. [PubMed: 12759223]

29. Cushman SW, Wardzala LJ. Potential mechanism of insulin action on glucose transport in the isolated rat adipose cell. Apparent translocation of intracellular transport systems to the plasma membrane. J Biol Chem. 1980; 255:4758-4762. [PubMed: 6989818]

30. Dassanayaka S, Jones SP. O-GlcNAc and the cardiovascular system. Pharmacol Ther. 2014; 142:62-71. [PubMed: 24287310]

31. Daugaard JR, Nielsen JN, Kristiansen S, Andersen JL, Hargreaves M, Richter EA. Fiber typespecific expression of GLUT4 in human skeletal muscle: influence of exercise training. Diabetes. 2000; 49:1092-1095. [PubMed: 10909963]

32. Davidson NO, Hausman AM, Ifkovits CA, Buse JB, Gould GW, Burant CF, Bell GI. Human intestinal glucose transporter expression and localization of GLUT5. Am J Physiol. 1992; 262:C795-C800. [PubMed: 1550217] 
33. Dawson PA, Mychaleckyj JC, Fossey SC, Mihic SJ, Craddock AL, Bowden DW. Sequence and functional analysis of GLUT10: a glucose transporter in the Type 2 diabetes-linked region of chromosome 20q12-13.1. Mol Genet Metab. 2001; 74:186-199. [PubMed: 11592815]

34. DeBosch B, Treskov I, Lupu TS, Weinheimer C, Kovacs A, Courtois M, Muslin AJ. Akt1 is required for physiological cardiac growth. Circulation. 2006; 113:2097-2104. [PubMed: 16636172]

35. Deng D, Xu C, Sun P, Wu J, Yan C, Hu M, Yan N. Crystal structure of the human glucose transporter GLUT1. Nature. 2014; 510:121-125. [PubMed: 24847886]

36. Depre C, Shipley GL, Chen W, Han Q, Doenst T, Moore ML, Stepkowski S, Davies PJ, Taegtmeyer H. Unloaded heart in vivo replicates fetal gene expression of cardiac hypertrophy. Nat Med. 1998; 4:1269-1275. [PubMed: 9809550]

37. Depre C, Vanoverschelde JL, Taegtmeyer H. Glucose for the heart. Circulation. 1999; 99:578-588. [PubMed: 9927407]

38. Des Rosiers C, Labarthe F, Lloyd SG, Chatham JC. Cardiac anaplerosis in health and disease: food for thought. Cardiovasc Res. 2011; 90:210-219. [PubMed: 21398307]

39. Desrois M, Sidell RJ, Gauguier D, Davey CL, Radda GK, Clarke K. Gender differences in hypertrophy, insulin resistance and ischemic injury in the aging type 2 diabetic rat heart. $\mathrm{J} \mathrm{Mol}$ Cell Cardiol. 2004; 37:547-555. [PubMed: 15276024]

40. Desrois M, Sidell RJ, Gauguier D, King LM, Radda GK, Clarke K. Initial steps of insulin signaling and glucose transport are defective in the type 2 diabetic rat heart. Cardiovasc Res. 2004; 61:288296. [PubMed: 14736545]

41. Dirkx E, Schwenk RW, Coumans WA, Hoebers N, Angin Y, Viollet B, Bonen A, van Eys GJ, Glatz JF, Luiken JJ. Protein kinase D1 is essential for contraction-induced glucose uptake but is not involved in fatty acid uptake into cardiomyocytes. J Biol Chem. 2012; 287:5871-5881. [PubMed: 22158620]

42. Doege H, Bocianski A, Joost HG, Schurmann A. Activity and genomic organization of human glucose transporter 9 (GLUT9), a novel member of the family of sugar-transport facilitators predominantly expressed in brain and leucocytes. Biochem J. 2000; 350(Pt 3):771-776. [PubMed: 10970791]

43. Doege H, Bocianski A, Scheepers A, Axer H, Eckel J, Joost HG, Schurmann A. Characterization of human glucose transporter (GLUT) 11 (encoded by SLC2A11), a novel sugar-transport facilitator specifically expressed in heart and skeletal muscle. Biochem J. 2001; 359:443-449. [PubMed: 11583593]

44. Doege H, Schurmann A, Bahrenberg G, Brauers A, Joost HG. GLUT8, a novel member of the sugar transport facilitator family with glucose transport activity. J Biol Chem. 2000; 275:1627516280. [PubMed: 10821868]

45. Doenst T, Cedars AM, Taegtmeyer H. Insulin-stimulated glucose transport is dependent on Golgi function in isolated working rat heart. J Mol Cell Cardiol. 2000; 32:1481-1488. [PubMed: 10900174]

46. Doenst T, Taegtmeyer H. alpha-adrenergic stimulation mediates glucose uptake through phosphatidylinositol 3-kinase in rat heart. Circulation research. 1999; 84:467-474. [PubMed: 10066682]

47. Dransfeld O, Uphues I, Sasson S, Schurmann A, Joost HG, Eckel J. Regulation of subcellular distribution of GLUT4 in cardiomyocytes: Rab4A reduces basal glucose transport and augments insulin responsiveness. Exp Clin Endocrinol Diabetes. 2000; 108:26-36. [PubMed: 10768829]

48. Efferth T, Schwarzl SM, Smith J, Osieka R. Role of glucose-6-phosphate dehydrogenase for oxidative stress and apoptosis. Cell Death Differ. 2006; 13:527-528. author reply 529-530. [PubMed: 16311511]

49. Egert S, Nguyen N, Brosius FC III, Schwaiger M. Effects of wortmannin on insulin- and ischemiainduced stimulation of GLUT4 translocation and FDG uptake in perfused rat hearts. Cardiovasc Res. 1997; 35:283-293. [PubMed: 9349391]

50. Egert S, Nguyen N, Schwaiger M. Contribution of alpha-adrenergic and beta-adrenergic stimulation to ischemia-induced glucose transporter (GLUT) 4 and GLUT1 translocation in the isolated perfused rat heart. Circ Res. 1999; 84:1407-1415. [PubMed: 10381893] 
51. El Alaoui-Talibi Z, Guendouz A, Moravec M, Moravec J. Control of oxidative metabolism in volume-overloaded rat hearts: Effect of propionyl-L-carnitine. Am J Physiol-Heart C. 1997; 272:H1615-H1624.

52. Facundo HT, Brainard RE, Watson LJ, Ngoh GA, Hamid T, Prabhu SD, Jones SP. O-GlcNAc signaling is essential for NFAT-mediated transcriptional reprogramming during cardiomyocyte hypertrophy. Am J Physiol-Heart C. 2012; 302:H2122-H2130.

53. Fandos C, Sanchez-Feutrie M, Santalucia T, Vinals F, Cadefau J, Guma A, Cusso R, Kaliman P, Canicio J, Palacin M, Zorzano A. GLUT1 glucose transporter gene transcription is repressed by Sp3. Evidence for a regulatory role of Sp3 during myogenesis. J Mol Biol. 1999; 294:103-119. [PubMed: 10556032]

54. Farese RV, Sajan MP, Yang H, Li P, Mastorides S, Gower WR Jr, Nimal S, Choi CS, Kim S, Shulman GI, Kahn CR, Braun U, Leitges M. Muscle-specific knockout of PKC-lambda impairs glucose transport and induces metabolic and diabetic syndromes. J Clin Invest. 2007; 117:22892301. [PubMed: 17641777]

55. Feldhaus LM, Liedtke AJ. mRNA expression of glycolytic enzymes and glucose transporter proteins in ischemic myocardium with and without reperfusion. J Mol Cell Cardiol. 1998; 30:2475-2485. [PubMed: 9925382]

56. Fico A, Paglialunga F, Cigliano L, Abrescia P, Verde P, Martini G, Iaccarino I, Filosa S. Glucose-6-phosphate dehydrogenase plays a crucial role in protection from redox-stress-induced apoptosis. Cell Death Differ. 2004; 11:823-831. [PubMed: 15044966]

57. Finck BN, Lehman JJ, Leone TC, Welch MJ, Bennett MJ, Kovacs A, Han X, Gross RW, Kozak R, Lopaschuk GD, Kelly DP. The cardiac phenotype induced by PPARalpha overexpression mimics that caused by diabetes mellitus. J Clin Invest. 2002; 109:121-130. [PubMed: 11781357]

58. Fischer Y, Thomas J, Holman GD, Rose H, Kammermeier H. Contraction-independent effects of catecholamines on glucose transport in isolated rat cardiomyocytes. Am J Physiol. 1996; 270:C1204-C1210. [PubMed: 8928747]

59. Fischer Y, Thomas J, Sevilla L, Munoz P, Becker C, Holman G, Kozka IJ, Palacin M, Testar X, Kammermeier H, Zorzano A. Insulin-induced recruitment of glucose transporter 4 (GLUT4) and GLUT1 in isolated rat cardiac myocytes. Evidence of the existence of different intracellular GLUT4 vesicle populations. J Biol Chem. 1997; 272:7085-7092. [PubMed: 9054401]

60. Fox AC, Reed GE. Changes in lactate dehydrogenase composition of hearts with right ventricular hypertrophy. Am J Physiol. 1969; 216:1026-1033. [PubMed: 5768047]

61. Fukumoto H, Kayano T, Buse JB, Edwards Y, Pilch PF, Bell GI, Seino S. Cloning and characterization of the major insulin-responsive glucose transporter expressed in human skeletalmuscle and other insulin-responsive tissues. J Biol Chem. 1989; 264:7776-7779. [PubMed: 2656669]

62. Fulop N, Feng W, Xing D, He K, Not LG, Brocks CA, Marchase RB, Miller AP, Chatham JC. Aging leads to increased levels of protein O-linked $\mathrm{N}$-acetylglucosamine in heart, aorta, brain and skeletal muscle in Brown-Norway rats. Biogerontology. 2008; 9:139-151. [PubMed: 18185980]

63. Garland PB, Randle PJ, Newsholme EA. Citrate as an intermediary in the inhibition of phosphofructokinase in rat heart muscle by fatty acids, ketone bodies, pyruvate, diabetes, and starvation. Nature. 1963; 200:169-170. [PubMed: 14073034]

64. Garvey WT, Hardin D, Juhaszova M, Dominguez JH. Effects of diabetes on myocardial glucose transport system in rats: Implications for diabetic cardiomyopathy. Am J Physiol. 1993; 264:H837-H844. [PubMed: 8456985]

65. Gibala MJ, Young ME, Taegtmeyer H. Anaplerosis of the citric acid cycle: Role in energy metabolism of heart and skeletal muscle. Acta Physiol Scand. 2000; 168:657-665. [PubMed: 10759602]

66. Gibbs EM, Stock JL, McCoid SC, Stukenbrok HA, Pessin JE, Stevenson RW, Milici AJ, McNeish JD. Glycemic improvement in diabetic $\mathrm{db} / \mathrm{db}$ mice by overexpression of the human insulinregulatable glucose transporter (GLUT4). J Clin Invest. 1995; 95:1512-1518. [PubMed: 7706456]

67. Goldfarb AH, Bruno JF, Buckenmeyer PJ. Intensity and duration effects of exercise on heart cAMP, phosphorylase, and glycogen. J Appl Physiol (1985). 1986; 60:1268-1273. [PubMed: 3009389] 
68. Goodwin GW, Arteaga JR, Taegtmeyer H. Glycogen turnover in the isolated working rat heart. J Biol Chem. 1995; 270:9234-9240. [PubMed: 7721842]

69. Goodwin GW, Taylor CS, Taegtmeyer H. Regulation of energy metabolism of the heart during acute increase in heart work. J Biol Chem. 1998; 273:29530-29539. [PubMed: 9792661]

70. Gosteli-Peter MA, Schmid C, Zapf J. Triiodothyronine increases glucose transporter isotype 4 mRNA expression, glucose transport, and glycogen synthesis in adult rat cardiomyocytes in longterm culture. Biochem Biophys Res Commun. 1996; 221:521-524. [PubMed: 8629994]

71. Gray SJ, Feinberg MW, Hull S, Kuo CT, Watanabe M, Sen Banerjee S, DePina A, Haspel R, Jain MK. The Kruppel-like factor KLF15 regulates the insulin-sensitive glucose transporter GLUT4. Circulation. 2002; 106:165-165.

72. Grover-McKay M, Walsh SA, Thompson SA. Glucose transporter 3 (GLUT3) protein is present in human myocardium. Biochim Biophys Acta. 1999; 1416:145-154. [PubMed: 9889355]

73. Gulve EA, Ren JM, Marshall BA, Gao J, Hansen PA, Holloszy JO, Mueckler M. Glucose transport activity in skeletal muscles from transgenic mice overexpressing GLUT1. Increased basal transport is associated with a defective response to diverse stimuli that activate GLUT4. J Biol Chem. 1994; 269:18366-18370. [PubMed: 8034582]

74. Gupte RS, Vijay V, Marks B, Levine RJ, Sabbah HN, Wolin MS, Recchia FA, Gupte SA. Upregulation of glucose-6-phosphate dehydrogenase and $\mathrm{NAD}(\mathrm{P}) \mathrm{H}$ oxidase activity increases oxidative stress in failing human heart. J Card Fail. 2007; 13:497-506. [PubMed: 17675065]

75. Gupte SA, Levine RJ, Gupte RS, Young ME, Lionetti V, Labinskyy V, Floyd BC, Ojaimi C, Bellomo M, Wolin MS, Recchia FA. Glucose-6-phosphate dehydrogenase-derived NADPH fuels superoxide production in the failing heart. J Mol Cell Cardiol. 2006; 41:340-349. [PubMed: 16828794]

76. Hall JL, Sexton WL, Stanley WC. Exercise training attenuates the reduction in myocardial Glut-4 in diabetic rats. J Appl Physiol. 1995; 78:76-81. [PubMed: 7713847]

77. Hansen PA, Gulve EA, Marshall BA, Gao J, Pessin JE, Holloszy JO, Mueckler M. Skeletal muscle glucose transport and metabolism are enhanced in transgenic mice overexpressing the Glut 4 glucose transporter. J Biol Chem. 1995; 270:1679-1684. [PubMed: 7829503]

78. Hecker PA, Leopold JA, Gupte SA, Recchia FA, Stanley WC. Impact of glucose-6-phosphate dehydrogenase deficiency on the pathophysiology of cardiovascular disease. Am J Physiol Heart Circ Physiol. 2013; 304:H491-H500. [PubMed: 23241320]

79. Hecker PA, Lionetti V, Ribeiro RF Jr, Rastogi S, Brown BH, O’Connell KA, Cox JW, Shekar KC, Gamble DM, Sabbah HN, Leopold JA, Gupte SA, Recchia FA, Stanley WC. Glucose 6-phosphate dehydrogenase deficiency increases redox stress and moderately accelerates the development of heart failure. Circ Heart Fail. 2013; 6:118-126. [PubMed: 23170010]

80. Heilig CW, Saunders T, Brosius FC III, Moley K, Heilig K, Baggs R, Guo L, Conner D. Glucose transporter-1-deficient mice exhibit impaired development and deformities that are similar to diabetic embryopathy. Proc Natl Acad Sci U S A. 2003; 100:15613-15618. [PubMed: 14673082]

81. Henning SL, Wambolt RB, Schonekess BO, Lopaschuk GD, Allard MF. Contribution of glycogen to aerobic myocardial glucose utilization. Circulation. 1996; 93:1549-1555. [PubMed: 8608624]

82. Hoenack C, Roesen P. Inhibition of angiotensin type 1 receptor prevents decline of glucose transporter (GLUT4) in diabetic rat heart. Diabetes. 1996; 45:S82-S87. [PubMed: 8529806]

83. Horecker BL, Mehler AH. Carbohydrate metabolism. Annu Rev Biochem. 1955; 24:207-274. [PubMed: 13249356]

84. Hrelia S, Fiorentini D, Maraldi T, Angeloni C, Bordoni A, Biagi PL, Hakim G. Doxorubicin induces early lipid peroxidation associated with changes in glucose transport in cultured cardiomyocytes. Biochim Biophys Acta. 2002; 1567:150-156. [PubMed: 12488048]

85. Hue L, Rider MH. Role of fructose 2,6-bisphosphate in the control of glycolysis in mammalian tissues. Biochem J. 1987; 245:313-324. [PubMed: 2822019]

86. Ikemoto S, Thompson KS, Takahashi M, Itakura H, Lane MD, Ezaki O. High fat diet-induced hyperglycemia: Prevention by low level expression of a glucose transporter (GLUT4) minigene in transgenic mice. Proc Natl Acad Sci U S A. 1995; 92:3096-3099. [PubMed: 7724522] 
87. Ishikura S, Bilan PJ, Klip A. Rabs 8A and 14 are targets of the insulin-regulated Rab-GAP AS160 regulating GLUT4 traffic in muscle cells. Biochem Biophys Res Commun. 2007; 353:1074-1079. [PubMed: 17208202]

88. Issad T, Kuo M. O-GlcNAc modification of transcription factors, glucose sensing and glucotoxicity. Trends Endocrinol Metab. 2008; 19:380-389. [PubMed: 18929495]

89. Jain M, Brenner DA, Cui L, Lim CC, Wang B, Pimentel DR, Koh S, Sawyer DB, Leopold JA, Handy DE, Apstein CS, Liao R. Glucose-6-phosphate dehydrogenase modulates cytosolic redox status and contractile phenotype in adult cardiomyocytes. Circulation. 2003; 108:173-173.

90. Jain M, Cui L, Brenner DA, Wang B, Handy DE, Leopold JA, Loscalzo J, Apstein CS, Liao R. Increased myocardial dysfunction after ischemia-reperfusion in mice lacking glucose-6-phosphate dehydrogenase. Circulation. 2004; 109:898-903. [PubMed: 14757696]

91. James DE, Hiken J, Lawrence JC Jr. Isoproterenol stimulates phosphorylation of the insulinregulatable glucose transporter in rat adipocytes. Proc Natl Acad Sci U S A. 1989; 86:8368-8372. [PubMed: 2554313]

92. Jenkins CM, Yang J, Sims HF, Gross RW. Reversible high affinity inhibition of phosphofructokinase-1 by acyl-CoA: A mechanism integrating glycolytic flux with lipid metabolism. J Biol Chem. 2011; 286:11937-11950. [PubMed: 21258134]

93. Jimenez-Amilburu V, Jong-Raadsen S, Bakkers J, Spaink HP, Marin-Juez R. GLUT12 deficiency during early development results in heart failure and a diabetic phenotype in zebrafish. J Endocrinol. 2015; 224:1-15. [PubMed: 25326603]

94. Johannsson E, Lunde PK, Heddle C, Sjaastad I, Thomas MJ, Bergersen L, Halestrap AP, Blackstad TW, Ottersen OP, Sejersted OM. Upregulation of the cardiac monocarboxylate transporter MCT1 in a rat model of congestive heart failure. Circulation. 2001; 104:729-734. [PubMed: 11489783]

95. Joost HG, Bell GI, Best JD, Birnbaum MJ, Charron MJ, Chen YT, Doege H, James DE, Lodish HF, Moley KH, Moley JF, Mueckler M, Rogers S, Schurmann A, Seino S, Thorens B. Nomenclature of the GLUT/SLC2A family of sugar/polyol transport facilitators. Am J Physiol Endocrinol Metab. 2002; 282:E974-E976. [PubMed: 11882521]

96. Joost HG, Thorens B. The extended GLUT-family of sugar/polyol transport facilitators: nomenclature, sequence characteristics, and potential function of its novel members (review). Mol Membr Biol. 2001; 18:247-256. [PubMed: 11780753]

97. Kagaya Y, Kanno Y, Takeyama D, Ishide N, Maruyama Y, Takahashi T, Ido T, Takishima T. Effects of long-term pressure overload on regional myocardial glucose and free fatty acid uptake in rats. A quantitative autoradiographic study. Circulation. 1990; 81:1353-1361. [PubMed: 2180593]

98. Kainulainen H, Breiner M, Schurmann A, Marttinen A, Virjo A, Joost HG. In-Vivo GlucoseUptake and Glucose-Transporter Proteins Glut1 and Glut4 in Heart and Various Types of SkeletalMuscle from Streptozotocin-Diabetic Rats. Bba-Mol Basis Dis. 1994; 1225:275-282.

99. Kane S, Sano H, Liu SC, Asara JM, Lane WS, Garner CC, Lienhard GE. A method to identify serine kinase substrates. Akt phosphorylates a novel adipocyte protein with a Rab GTPaseactivating protein (GAP) domain. J Biol Chem. 2002; 277:22115-22118. [PubMed: 11994271]

100. Kasahara M, Hinkle PC. Reconstitution and purification of the D-glucose transporter from human erythrocytes. J Biol Chem. 1977; 252:7384-7390. [PubMed: 903365]

101. Katz EB, Stenbit AE, Hatton K, DePinho R, Charron MJ. Cardiac and adipose tissue abnormalities but not diabetes in mice deficient in GLUT4. Nature. 1995; 377:151-155. [PubMed: 7675081]

102. Kayano T, Burant CF, Fukumoto H, Gould GW, Fan YS, Eddy RL, Byers MG, Shows TB, Seino S, Bell GI. Human facilitative glucose transporters - isolation, functional-characterization, and gene localization of Cdnas encoding an isoform (Glut5) expressed in small-intestine, kidney, muscle, and adipose-tissue and an unusual glucose transporter pseudogene-like sequence (Glut6). J Biol Chem. 1990; 265:13276-13282. [PubMed: 1695905]

103. Kayano T, Fukumoto H, Eddy RL, Fan YS, Byers MG, Shows TB, Bell GI. Evidence for a family of human glucose transporter-like proteins -sequence and gene localization of a protein expressed in fetal skeletal-muscle and other tissues. J Biol Chem. 1988; 263:15245-15248. [PubMed: 3170580] 
104. Kolwicz SC Jr, Olson DP, Marney LC, Garcia-Menendez L, Synovec RE, Tian R. Cardiacspecific deletion of acetyl CoA carboxylase 2 prevents metabolic remodeling during pressureoverload hypertrophy. Circ Res. 2012; 111:728-738. [PubMed: 22730442]

105. Kopp SJ, Daar J, Paulson DJ, Romano FD, Laddaga R. Effects of oral vanadyl treatment on diabetes induced alterations in the heart GLUT-4 transporter. J Mol Cell Cardiol. 1997; 29:23552362. [PubMed: 9299359]

106. Korvald C, Elvenes OP, Myrmel T. Myocardial substrate metabolism influences left ventricular energetics in vivo. Am J Physiol Heart Circ Physiol. 2000; 278:H1345-H1351. [PubMed: 10749732]

107. Kotani K, Ogawa W, Matsumoto M, Kitamura T, Sakaue H, Hino Y, Miyake K, Sano W, Akimoto K, Ohno S, Kasuga M. Requirement of atypical protein kinase clambda for insulin stimulation of glucose uptake but not for Akt activation in 3T3-L1 adipocytes. Mol Cell Biol. 1998; 18:6971-6982. [PubMed: 9819385]

108. Kraegen EW, Sowden JA, Halstead MB, Clark PW, Rodnick KJ, Chisholm DJ, James DE. Glucose transporters and in vivo glucose uptake in skeletal and cardiac muscle: Fasting, insulin stimulation and immunoisolation studies of GLUT1 and GLUT4. Biochem J. 1993; 295(Pt 1): 287-293. [PubMed: 8216230]

109. Kramer HF, Witczak CA, Fujii N, Jessen N, Taylor EB, Arnolds DE, Sakamoto K, Hirshman MF, Goodyear LJ. Distinct signals regulate AS160 phosphorylation in response to insulin, AICAR, and contraction in mouse skeletal muscle. Diabetes. 2006; 55:2067-2076. [PubMed: 16804077]

110. Kudo N, Barr AJ, Barr RL, Desai S, Lopaschuk GD. High rates of fatty acid oxidation during reperfusion of ischemic hearts are associated with a decrease in malonyl-CoA levels due to an increase in 5'-AMP-activated protein kinase inhibition of acetyl-CoA carboxylase. J Biol Chem. 1995; 270:17513-17520. [PubMed: 7615556]

111. Laczy B, Hill BG, Wang K, Paterson AJ, White CR, Xing D, Chen YF, Darley-Usmar V, Oparil S, Chatham JC. Protein O-GlcNAcylation: A new signaling paradigm for the cardiovascular system. Am J Physiol-Heart C. 2009; 296:H13-H28.

112. Larance M, Ramm G, Stockli J, van Dam EM, Winata S, Wasinger V, Simpson F, Graham M, Junutula JR, Guilhaus M, James DE. Characterization of the role of the Rab GTPase-activating protein AS160 in insulin-regulated GLUT4 trafficking. J Biol Chem. 2005; 280:37803-37813. [PubMed: 16154996]

113. Lawrence JC Jr, Hiken JF, James DE. Phosphorylation of the glucose transporter in rat adipocytes. Identification of the intracellular domain at the carboxyl terminus as a target for phosphorylation in intact-cells and in vitro. J Biol Chem. 1990; 265:2324-2332. [PubMed: 2404983]

114. Laybutt DR, Thompson AL, Cooney GJ, Kraegen EW. Selective chronic regulation of GLUT1 and GLUT4 content by insulin, glucose, and lipid in rat cardiac muscle in vivo. Am J Physiol. 1997; 273:H1309-H1316. [PubMed: 9321820]

115. Le Marchand-Brustel Y, Gautier N, Cormont M, Van Obberghen E. Wortmannin inhibits the action of insulin but not that of okadaic acid in skeletal muscle: comparison with fat cells. Endocrinology. 1995; 136:3564-3570. [PubMed: 7628394]

116. Lee L, Campbell R, Scheuermann-Freestone M, Taylor R, Gunaruwan P, Williams L, Ashrafian H, Horowitz J, Fraser AG, Clarke K, Frenneaux M. Metabolic modulation with perhexiline in chronic heart failure - a randomized, controlled trial of short-term use of a novel treatment. Circulation. 2005; 112:3280-3288. [PubMed: 16301359]

117. Lehman JJ, Kelly DP. Transcriptional activation of energy metabolic switches in the developing and hypertrophied heart. Clin Exp Pharmacol P. 2002; 29:339-345.

118. Lemieux MJ, Song J, Kim MJ, Huang Y, Villa A, Auer M, Li XD, Wang DN. Three-dimensional crystallization of the Escherichia coli glycerol-3-phosphate transporter: a member of the major facilitator superfamily. Protein Sci. 2003; 12:2748-2756. [PubMed: 14627735]

119. Leong HS, Brownsey RW, Kulpa JE, Allard MF. Glycolysis and pyruvate oxidation in cardiac hypertrophy-why so unbalanced? Comp Biochem Physiol A Mol Integr Physiol. 2003; 135:499_ 513. [PubMed: 12890541] 
120. Leong HS, Grist M, Parsons H, Wambolt RB, Lopaschuk GD, Brownsey R, Allard MF. Accelerated rates of glycolysis in the hypertrophied heart: Are they a methodological artifact? Am J Physiol Endocrinol Metab. 2002; 282:E1039-H1045. [PubMed: 11934668]

121. Leturque A, Loizeau M, Vaulont S, Salminen M, Girard J. Improvement of insulin action in diabetic transgenic mice selectively overexpressing GLUT4 in skeletal muscle. Diabetes. 1996; 45:23-27. [PubMed: 8522055]

122. Lewandowski ED, O'Donnell JM, Scholz TD, Sorokina N, Buttrick PM. Recruitment of NADH shuttling in pressure-overloaded and hypertrophic rat hearts. Am J Physiol Cell Physiol. 2007; 292:C1880-C1886. [PubMed: 17229809]

123. Li J, Hu X, Selvakumar P, Russell RR III, Cushman SW, Holman GD, Young LH. Role of the nitric oxide pathway in AMPK-mediated glucose uptake and GLUT4 translocation in heart muscle. Am J Physiol Endocrinol Metab. 2004; 287:E834-E841. [PubMed: 15265762]

124. Li Q, Manolescu A, Ritzel M, Yao S, Slugoski M, Young JD, Chen XZ, Cheeseman CI. Cloning and functional characterization of the human GLUT7 isoform SLC2A7 from the small intestine. Am J Physiol-Gastr L. 2004; 287:G236-G242.

125. Liao R, Jain M, Cui L, D’Agostino J, Aiello F, Luptak I, Ngoy S, Mortensen RM, Tian R. Cardiac-specific overexpression of GLUT1 prevents the development of heart failure attributable to pressure overload in mice. Circulation. 2002; 106:2125-2131. [PubMed: 12379584]

126. Lisinski I, Schurmann A, Joost HG, Cushman SW, Al-Hasani H. Targeting of GLUT6 (formerly GLUT9) and GLUT8 in rat adipose cells. Biochem J. 2001; 358:517-522. [PubMed: 11513753]

127. Liu J, Kimura A, Baumann CA, Saltiel AR. APS facilitates c-Cbl tyro-sine phosphorylation and GLUT4 translocation in response to insulin in 3T3-L1 adipocytes. Mol Cell Biol. 2002; 22:35993609. [PubMed: 11997497]

128. Liu ML, Olson AL, Edgington NP, Moyerowley WS, Pessin JE. Myocyte enhancer factor-2 (Mef2) binding-site is essential for C2c12 myotube-specific expression of the rat Glut4 muscleadipose facilitative glucose-transporter gene. J Biol Chem. 1994; 269:28514-28521. [PubMed: 7545962]

129. Liu ML, Olson AL, Moye-Rowley WS, Buse JB, Bell GI, Pessin JE. Expression and regulation of the human GLUT4/muscle-fat facilitative glucose transporter gene in transgenic mice. J Biol Chem. 1992; 267:11673-11676. [PubMed: 1601840]

130. Lopaschuk GD, Ussher JR, Folmes CDL, Jaswal JS, Stanley WC. Myocardial fatty acid metabolism in health and disease. Physiol Rev. 2010; 90:207-258. [PubMed: 20086077]

131. Lu Z, Zaniewska E, Lo TCY. Use of transport mutants to examine the identity and expression of GLUT isoforms in rat cardiac myoblasts. Biochem Mol Biol Int. 1997; 41:103-121. [PubMed: 9043640]

132. Luiken JJ, Ouwens DM, Habets DD, van der Zon GC, Coumans WA, Schwenk RW, Bonen A, Glatz JF. Permissive action of protein kinase C-zeta in insulin-induced CD36- and GLUT4 translocation in cardiac myocytes. J Endocrinol. 2009; 201:199-209. [PubMed: 19273501]

133. Luiken JJ, Vertommen D, Coort SL, Habets DD, El Hasnaoui M, Pelsers MM, Viollet B, Bonen A, Hue L, Rider MH, Glatz JF. Identification of protein kinase D as a novel contraction-activated kinase linked to GLUT4-mediated glucose uptake, independent of AMPK. Cell Signal. 2008; 20:543-556. [PubMed: 18164589]

134. Lund S, Holman GD, Schmitz O, Pedersen O. Contraction stimulates translocation of glucose transporter GLUT4 in skeletal muscle through a mechanism distinct from that of insulin. Proc Natl Acad Sci U S A. 1995; 92:5817-5821. [PubMed: 7597034]

135. Luptak I, Yan J, Cui L, Jain M, Liao R, Tian R. Long-term effects of increased glucose entry on mouse hearts during normal aging and ischemic stress. Circulation. 2007; 116:901-909. [PubMed: 17679614]

136. Lydell CP, Chan A, Wambolt RB, Sambandam N, Parsons H, Bondy GP, Rodrigues B, Popov KM, Harris RA, Brownsey RW, Allard MF. Pyruvate dehydrogenase and the regulation of glucose oxidation in hypertrophied rat hearts. Cardiovasc Res. 2002; 53:841-851. [PubMed: 11922894] 
137. Macheda ML, Kelly DJ, Best JD, Rogers S. Expression during rat fetal development of GLUT12 - a member of the class III hexose transporter family. Anat Embryol. 2002; 205:441-452. [PubMed: 12382147]

138. Malhotra R, Brosius FC III. Glucose uptake and glycolysis reduce hypoxia-induced apoptosis in cultured neonatal rat cardiac myocytes. J Biol Chem. 1999; 274:12567-12575. [PubMed: 10212235]

139. Marchington DR, Kerbey AL, Randle PJ. Longer-term regulation of pyruvate-dehydrogenase kinase in cultured rat cardiac myocytes. Biochem J. 1990; 267:245-247. [PubMed: 2158309]

140. Marino G, Pietrocola F, Eisenberg T, Kong Y, Malik SA, Andryushkova A, Schroeder S, Pendl T, Harger A, Niso-Santano M, Zamzami N, Scoazec M, Durand S, Enot DP, Fernandez AF, Martins I, Kepp O, Senovilla L, Bauvy C, Morselli E, Vacchelli E, Bennetzen M, Magnes C, Sinner F, Pieber T, Lopez-Otin C, Maiuri MC, Codogno P, Andersen JS, Hill JA, Madeo F, Kroemer G. Regulation of autophagy by cytosolic acetyl-coenzyme A. Mol Cell. 2014; 53:710 725. [PubMed: 24560926]

141. Marsh SA, Collins HE, Chatham JC. Protein O-GlcNAcylation and Cardiovascular (Patho)physiology. J Biol Chem. 2014; 289:34449-34456. [PubMed: 25336635]

142. Marsh SA, Dell'Italia LJ, Chatham JC. Activation of the hexosamine biosynthesis pathway and protein O-GlcNAcylation modulate hypertrophic and cell signaling pathways in cardiomyocytes from diabetic mice. Amino Acids. 2011; 40:819-828. [PubMed: 20676904]

143. Marsin AS, Bertrand L, Rider MH, Deprez J, Beauloye C, Vincent MF, Van den Berghe G, Carling D, Hue L. Phosphorylation and activation of heart PFK-2 by AMPK has a role in the stimulation of glycolysis during ischaemia. Curr Biol. 2000; 10:1247-1255. [PubMed: 11069105]

144. McVie-Wylie AJ, Lamson DR, Chen YT. Molecular cloning of a novel member of the GLUT family of transporters, SLC2a10 (GLUT10), localized on chromosome 20q13.1: A candidate gene for NIDDM susceptibility. Genomics. 2001; 72:113-117. [PubMed: 11247674]

145. Meerson FZ, Spiritchev VB, Pshennikova MG, Djachkova LV. The role of the pentose-phosphate pathway in adjustment of the heart to a high load and the development of myocardial hypertrophy. Experientia. 1967; 23:530-532. [PubMed: 4228586]

146. Membrez M, Hummler E, Beermann F, Haefliger JA, Savioz R, Pedrazzini T, Thorens B. GLUT8 is dispensable for embryonic development but influences hippocampal neurogenesis and heart function. Mol Cell Biol. 2006; 26:4268-4276. [PubMed: 16705176]

147. Michael LF, Wu ZD, Cheatham RB, Puigserver P, Adelmant G, Lehman JJ, Kelly DP, Spiegelman BM. Restoration of insulin-sensitive glucose transporter (GLUT4) gene expression in muscle cells by the transcriptional coactivator PGC-1. P Natl Acad Sci U S A. 2001; 98:38203825.

148. Miinea CP, Sano H, Kane S, Sano E, Fukuda M, Peranen J, Lane WS, Lienhard GE. AS160, the Akt substrate regulating GLUT4 translocation, has a functional Rab GTPase-activating protein domain. Biochem J. 2005; 391:87-93. [PubMed: 15971998]

149. Mitra P, Zheng X, Czech MP. RNAi-based analysis of CAP, Cbl, and CrkII function in the regulation of GLUT4 by insulin. J Biol Chem. 2004; 279:37431-37435. [PubMed: 15258163]

150. Mochizuki S, Neely JR. Control of glyceraldehyde-3-phosphate dehydrogenase in cardiac muscle. J Mol Cell Cardiol. 1979; 11:221-236. [PubMed: 34041]

151. Molero JC, Jensen TE, Withers PC, Couzens M, Herzog H, Thien CB, Langdon WY, Walder K, Murphy MA, Bowtell DD, James DE, Cooney GJ. c-Cbl-deficient mice have reduced adiposity, higher energy expenditure, and improved peripheral insulin action. J Clin Invest. 2004; 114:1326-1333. [PubMed: 15520865]

152. Montessuit C, Papageorgiou I, Remondino-Muller A, Tardy I, Lerch R. Post-ischemic stimulation of 2-deoxyglucose uptake in rat myocardium: role of translocation of Glut-4. J Mol Cell Cardiol. 1998; 30:393-403. [PubMed: 9515016]

153. Montessuit $\mathrm{C}$, Thorburn A. Transcriptional activation of the glucose transporter GLUT1 in ventricular cardiac myocytes by hypertrophic agonists. J Biol Chem. 1999; 274:9006-9012. [PubMed: 10085148] 
154. Mor I, Cheung EC, Vousden KH. Control of glycolysis through regulation of PFK1: Old friends and recent additions. Cold Spring Harb Symp Quant Biol. 2011; 76:211-216. [PubMed: 22096029]

155. Mora A, Komander D, van Aalten DM, Alessi DR. PDK1, the master regulator of AGC kinase signal transduction. Semin Cell Dev Biol. 2004; 15:161-170. [PubMed: 15209375]

156. Mora S, Yang CM, Ryder JW, Boeglin D, Pessin JE. The MEF2A and MEF2D isoforms are differentially regulated in muscle and adipose tissue during states of insulin deficiency. Endocrinology. 2001; 142:1999-2004. [PubMed: 11316766]

157. Moreno H, Serrano AL, Santalucia T, Guma A, Canto C, Brand NJ, Palacin M, Schiaffino S, Zorzano A. Differential regulation of the muscle-specific GLUT4 enhancer in regenerating and adult skeletal muscle. J Biol Chem. 2003; 278:40557-40564. [PubMed: 12893821]

158. Moule SK, Denton RM. Multiple signaling pathways involved in the metabolic effects of insulin. Am J Cardiol. 1997; 80:41A-49A.

159. Mueckler M. Facilitative glucose transporters. Eur J Biochem. 4991; 912:527-317.

160. Mueckler M, Caruso C, Baldwin SA, Panico M, Blench I, Morris HR, Allard WJ, Lienhard GE, Lodish HF. Sequence and structure of a human glucose transporter. Science. 1985; 229:941-945. [PubMed: 3839598]

161. Mueckler M, Hresko RC, Sato M. Structure, function and biosynthesis of GLUT1. Biochem Soc Trans. 1997; 25:951-954. [PubMed: 9388579]

162. Nascimben L, Ingwall JS, Lorell BH, Pinz I, Schultz V, Tornheim K, Tian R. Mechanisms for increased glycolysis in the hypertrophied rat heart. Hypertension. 2004; 44:662-667. [PubMed: 15466668]

163. Neely JR, Whitfiel Cf, Morgan HE. Regulation of glycogenolysis in hearts: Effects of pressure development, glucose, and FFA. Am J Physiol. 1970; 219:1083-1088. [PubMed: 5459473]

164. Neubauer S. The failing heart-an engine out of fuel. N Engl J Med. 2007; 356:1140-1151. [PubMed: 17360992]

165. Opie LH. The metabolic vicious cycle in heart failure. Lancet. 2004; 364:1733-1734. [PubMed: 15541431]

166. Opie LH. Myocardial energy metabolism. Adv Cardiol. 1974; 12:70-83. [PubMed: 4365502]

167. Osborn BA, Daar JT, Laddaga RA, Romano FD, Paulson DJ. Exercise training increases sarcolemmal GLUT-4 protein and mRNA content in diabetic heart. J Appl Physiol. 1997; 82:828-834. [PubMed: 9074970]

168. Oshel KM, Knight JB, Cao KT, Thai MV, Olson AL. Identification of a 30-base pair regulatory element and novel DNA binding protein that regulates the human GLUT4 promoter in transgenic mice. J Biol Chem. 2000; 275:23666-23673. [PubMed: 10825161]

169. Pao SS, Paulsen IT, Saier MH Jr. Major facilitator superfamily. Microbiol Mol Biol Rev. 1998; 62:1-34. [PubMed: 9529885]

170. Paternostro G, Clarke K, Heath J, Seymour AM, Radda GK. Decreased GLUT-4 mRNA content and insulin-sensitive deoxyglucose uptake show insulin resistance in the hypertensive rat heart. Cardiovasc Res. 1995; 30:205-211. [PubMed: 7585807]

171. Paternostro G, Pagano D, Gnecchi-Ruscone T, Bonser RS, Camici PG. Insulin resistance in patients with cardiac hypertrophy. Cardiovasc Res. 1999; 42:246-253. [PubMed: 10435017]

172. Pelletier A, Joly E, Prentki M, Coderre L. Adenosine 5'-monophosphate-activated protein kinase and p38 mitogen-activated protein kinase participate in the stimulation of glucose uptake by dinitrophenol in adult cardiomyocytes. Endocrinology. 2005; 146:2285-2294. [PubMed: 15677757]

173. Pereira RO, Wende AR, Olsen C, Soto J, Rawlings T, Zhu Y, Anderson SM, Abel ED. Inducible overexpression of GLUT1 prevents mitochondrial dysfunction and attenuates structural remodeling in pressure overload but does not prevent left ventricular dysfunction. J Am Heart Assoc. 2013; 2:e000301. [PubMed: 24052497]

174. Phay JE, Hussain HB, Moley JF. Strategy for identification of novel glucose transporter family members by using internet-based genomic databases. Surgery. 2000; 128:946-951. [PubMed: 11114628] 
175. Pound KM, Sorokina N, Ballal K, Berkich DA, Fasano M, LaNoue KF, Taegtmeyer H, O'Donnell JM, Lewandowski ED. Substrate-enzyme competition attenuates upregulated anaplerotic flux through malic enzyme in hypertrophied rat heart and restores triacylglyceride content: Attenuating upregulated anaplerosis in hypertrophy (vol 104, pg 805, 2009). Circ Res. 2009; 104:E59-E59.

176. Rajasekaran NS, Connell P, Christians ES, Yan LJ, Taylor RP, Orosz A, Zhang XQ, Stevenson TJ, Peshock RM, Leopold JA, Barry WH, Loscalzo J, Odelberg SJ, Benjamin IJ. Human alpha B-crystallin mutation causes oxido-reductive stress and protein aggregation cardiomyopathy in mice. Cell. 2007; 130:427-439. [PubMed: 17693254]

177. Randle PJ, Garland PB, Hales CN, Newsholme EA. The glucose fatty-acid cycle. Its role in insulin sensitivity and the metabolic disturbances of diabetes mellitus. Lancet. 1963; 1:785-789. [PubMed: 13990765]

178. Randle PJ, Newsholme EA, Garland PB. Regulation of glucose uptake by muscle. 8. Effects of fatty acids, ketone bodies and pyruvate, and of alloxan-diabetes and starvation, on the uptake and metabolic fate of glucose in rat heart and diaphragm muscles. Biochem J. 1964; 93:652-665. [PubMed: 4220952]

179. Rattigan S, Appleby GJ, Clark MG. Insulin-like action of catecholamines and Ca2+ to stimulate glucose transport and GLUT4 translocation in perfused rat heart. Biochim Biophys Acta. 1991; 1094:217-223. [PubMed: 1909899]

180. Razeghi P, Young ME, Alcorn JL, Moravec CS, Frazier OH, Taegtmeyer H. Metabolic gene expression in fetal and failing human heart. Circulation. 2001; 104:2923-2931. [PubMed: 11739307]

181. Razeghi P, Young ME, Cockrill TC, Frazier OH, Taegtmeyer H. Downregulation of myocardial myocyte enhancer factor $2 \mathrm{C}$ and myocyte enhancer factor $2 \mathrm{C}$-regulated gene expression in diabetic patients with nonischemic heart failure. Circulation. 2002; 106:407-411. [PubMed: 12135937]

182. Razeghi P, Young ME, Ying J, Depre C, Uray IP, Kolesar J, Shipley GL, Moravec CS, Davies PJA, Frazier OH, Taegtmeyer H. Downregulation of metabolic gene expression in failing human heart before and after mechanical unloading. Cardiology. 2002; 97:203-209. [PubMed: 12145475]

183. Ren J, Gintant GA, Miller RE, Davidoff AJ. High extracellular glucose impairs cardiac E-C coupling in a glycosylation-dependent manner. Am J Physiol. 1997; 273:H2876-H2883. [PubMed: 9435627]

184. Revis NW, Thomson RY, Cameron AJ. Lactate dehydrogenase isoenzymes in the human hypertrophic heart. Cardiovasc Res. 1977; 11:172-176. [PubMed: 140006]

185. Rodnick KJ, Henriksen EJ, James DE, Holloszy JO. Exercise training, glucose transporters, and glucose transport in rat skeletal muscles. Am J Physiol. 1992; 262:C9-C14. [PubMed: 1733237]

186. Rogers S, Chandler JD, Clarke AL, Petrou S, Best JD. Glucose transporter GLUT12-functional characterization in Xenopus laevis oocytes. Biochem Bioph Res Co. 2003; 308:422-426.

187. Rosenblatt-Velin N, Montessuit C, Papageorgiou I, Terrand M, Lerch R. Postinfarction heart failure in rats is associated with upregulation of GLUT-1 and downregulation of genes of fatty acid metabolism. Cardiovasc Res. 2001; 52:407-416. [PubMed: 11738057]

188. Roy D, Perreault M, Marette A. Insulin stimulation of glucose uptake in skeletal muscles and adipose tissues in vivo is NO dependent. Am J Physiol. 1998; 274:E692-E699. [PubMed: 9575831]

189. Rupert BE, Schutte BC, TenEyck CJ, Scholz TD. Metabolic adaptation of the hypertrophied heart: Role of the malate/aspartate and alpha-glycerophosphate shuttles. Circulation. 1999; 100:765-765.

190. Russell RR III, Bergeron R, Shulman GI, Young LH. Translocation of myocardial GLUT-4 and increased glucose uptake through activation of AMPK by AICAR. Am J Physiol. 1999; 277:H643-H649. [PubMed: 10444490]

191. Russell RR III, Li J, Coven DL, Pypaert M, Zechner C, Palmeri M, Giordano FJ, Mu J, Birnbaum MJ, Young LH. AMP-activated protein kinase mediates ischemic glucose uptake and prevents 
postischemic cardiac dysfunction, apoptosis, and injury. J Clin Invest. 2004; 114:495-503. [PubMed: 15314686]

192. Ryder JW, Kawano Y, Chibalin AV, Rincon J, Tsao TS, Stenbit AE, Combatsiaris T, Yang J, Holman GD, Charron MJ, Zierath JR. In vitro analysis of the glucose-transport system in GLUT4-null skeletal muscle. Biochem J. 1999; 342(Pt 2):321-328. [PubMed: 10455018]

193. Safer B. The metabolic significance of the malate-aspartate cycle in heart. Circ Res. 1975; 37:527-533. [PubMed: 172258]

194. Salas-Burgos A, Iserovich P, Zuniga F, Vera JC, Fischbarg J. Predicting the three-dimensional structure of the human facilitative glucose transporter glut1 by a novel evolutionary homology strategy: Insights on the molecular mechanism of substrate migration, and binding sites for glucose and inhibitory molecules. Biophys J. 2004; 87:2990-2999. [PubMed: 15326030]

195. Samant SA, Courson DS, Sundaresan NR, Pillai VB, Tan MJ, Zhao YM, Shroff SG, Rock RS, Gupta MP. HDAC3-dependent reversible lysine acetylation of cardiac myosin heavy chain isoforms modulates their enzymatic and motor activity. J Biol Chem. 2011; 286:5567-5577. [PubMed: 21177250]

196. Sano H, Eguez L, Teruel MN, Fukuda M, Chuang TD, Chavez JA, Lienhard GE, McGraw TE. Rab10, a target of the AS160 Rab GAP, is required for insulin-stimulated translocation of GLUT4 to the adipocyte plasma membrane. Cell metabolism. 2007; 5:293-303. [PubMed: 17403373]

197. Sano H, Kane S, Sano E, Miinea CP, Asara JM, Lane WS, Garner CW, Lienhard GE. Insulinstimulated phosphorylation of a Rab GTPase-activating protein regulates GLUT4 translocation. J Biol Chem. 2003; 278:14599-14602. [PubMed: 12637568]

198. Santalucia T, Boheler KR, Brand NJ, Sahye U, Fandos C, Vinals F, Ferre J, Testar X, Palacin M, Zorzano A. Factors involved in GLUT-1 glucose transporter gene transcription in cardiac muscle. J Biol Chem. 1999; 274:17626-17634. [PubMed: 10364200]

199. Santalucia T, Christmann M, Yacoub MH, Brand NJ. Hypertrophic agonists induce the binding of c-Fos to an AP-1 site in cardiac myocytes: Implications for the expression of GLUT1. Cardiovasc Res. 2003; 59:639-648. [PubMed: 14499865]

200. Santalucia T, Moreno H, Palacin M, Yacoub MH, Brand NJ, Zorzano A. A novel functional cooperation between MyoD, MEF2 and TR alpha 1 is sufficient for the induction of GLUT4 gene transcription. J Mol Biol. 2001; 314:195-204. [PubMed: 11718554]

201. Satoh S, Nishimura H, Clark AE, Kozka IJ, Vannucci SJ, Simpson IA, Quon MJ, Cushman SW, Holman GD. Use of bismannose photolabel to elucidate insulin-regulated GLUT4 subcellular trafficking kinetics in rat adipose cells. Evidence that exocytosis is a critical site of hormone action. J Biol Chem. 1993; 268:17820-17829. [PubMed: 8349666]

202. Scheepers A, Schmidt S, Manolescu A, Cheeseman CI, Bell A, Zahn C, Joost HG, Schurmann A. Characterization of the human SLC2A11 (GLUT11) gene: Alternative promoter usage, function, expression, and subcellular distribution of three isoforms, and lack of mouse orthologue. Mol Membr Biol. 2005; 22:339-351. [PubMed: 16154905]

203. Schmidt S, Joost HG, Schurmann A. GLUT8, the enigmatic intracellular hexose transporter. Am J Physiol-Endoc M. 2009; 296:E614-E618.

204. Schmidt-Schweda S, Holubarsch C. First clinical trial with etomoxir in patients with chronic congestive heart failure. Clin Sci. 2000; 99:27-35. [PubMed: 10887055]

205. Schneider CA, Nguyen VT, Taegtmeyer H. Feeding and fasting determine postischemic glucose utilization in isolated working rat hearts. Am J Physiol. 1991; 260:H542-H548. [PubMed: 1996697]

206. Scholz TD, Koppenhafer SL, TenEyck CJ, Schutte BC. Developmental regulation of the alphaglycerophosphate shuttle in porcine myocardium. J Mol Cell Cardiol. 1997; 29:1605-1613. [PubMed: 9220346]

207. Scholz TD, Koppenhafer SL, tenEyck CJ, Schutte BC. Ontogeny of malate-aspartate shuttle capacity and gene expression in cardiac mitochondria. Am J Physiol. 1998; 274:C780-C788. [PubMed: 9530110] 
208. Schonekess BO, Allard MF, Henning SL, Wambolt RB, Lopaschuk GD. Contribution of glycogen and exogenous glucose to glucose metabolism during ischemia in the hypertrophied rat heart. Circ Res. 1997; 81:540-549. [PubMed: 9314835]

209. Schonekess BO, Allard MF, Lopaschuk GD. Propionyl L-carnitine improvement of hypertrophied heart function is accompanied by an increase in carbohydrate oxidation. Circ Res. 1995; 77:726734. [PubMed: 7554119]

210. Shankar RR, Wu Y, Shen HQ, Zhu JS, Baron AD. Mice with gene disruption of both endothelial and neuronal nitric oxide synthase exhibit insulin resistance. Diabetes. 2000; 49:684-687. [PubMed: 10905473]

211. Shepherd PR, Kahn BB. Mechanisms of disease - glucose transporters and insulin action implications for insulin resistance and diabetes mellitus. New Engl J Med. 1999; 341:248-257. [PubMed: 10413738]

212. Sidell RJ, Cole MA, Draper NJ, Desrois M, Buckingham RE, Clarke K. Thiazolidinedione treatment normalizes insulin resistance and ischemic injury in the zucker fatty rat heart. Diabetes. 2002; 51:1110-1117. [PubMed: 11916933]

213. Sivitz WI, Lund DD, Yorek B, Grover-McKay M, Schmid PG. Pretranslational regulation of two cardiac glucose transporters in rats exposed to hypobaric hypoxia. Am J Physiol. 1992; 263:E562-E569. [PubMed: 1415537]

214. Slot JW, Geuze HJ, Gigengack S, James DE, Lienhard GE. Translocation of the glucose transporter GLUT4 in cardiac myocytes of the rat. Proc Natl Acad Sci U S A. 1991; 88:78157819. [PubMed: 1881917]

215. Smith SH, Kramer MF, Reis I, Bishop SP, Ingwall JS. Regional changes in creatine kinase and myocyte size in hypertensive and nonhypertensive cardiac hypertrophy. Circ Res. 1990; 67:1334-1344. [PubMed: 2147129]

216. Sorokina N, O’Donnell JM, McKinney RD, Pound KM, Woldegiorgis G, LaNoue KF, Ballal K, Taegtmeyer H, Buttrick PM, Lewandowski ED. Recruitment of compensatory pathways to sustain oxidative flux with reduced carnitine palmitoyltransferase I activity characterizes inefficiency in energy metabolism in hypertrophied hearts. Circulation. 2007; 115:2033-2041. [PubMed: 17404155]

217. Standaert ML, Bandyopadhyay G, Perez L, Price D, Galloway L, Poklepovic A, Sajan MP, Cenni V, Sirri A, Moscat J, Toker A, Farese RV. Insulin activates protein kinases C-zeta and C-lambda by an autophosphorylation-dependent mechanism and stimulates their translocation to GLUT4 vesicles and other membrane fractions in rat adipocytes. J Biol Chem. 1999; 274:25308-25316. [PubMed: 10464256]

218. Stanley WC, Lopaschuk GD, Hall JL, McCormack JG. Regulation of myocardial carbohydrate metabolism under normal and ischaemic conditions. Potential for pharmacological interventions. Cardiovasc Res. 1997; 33:243-257. [PubMed: 9074687]

219. Stanley WC, Recchia FA, Lopaschuk GD. Myocardial substrate metabolism in the normal and failing heart. Physiol Rev. 2005; 85:1093-1129. [PubMed: 15987803]

220. Stenbit AE, Tsao TS, Li J, Burcelin R, Geenen DL, Factor SM, Houseknecht K, Katz EB, Charron MJ. GLUT4 heterozygous knockout mice develop muscle insulin resistance and diabetes. Nat Med. 1997; 3:1096-1101. [PubMed: 9334720]

221. Stephens JM, Pilch PF. The metabolic-regulation and vesicular transport of Glut 4 , the major insulin-responsive glucose-transporter. Endocr Rev. 1995; 16:529-546. [PubMed: 8521793]

222. Stretton C, Evans A, Hundal HS. Cellular depletion of atypical PKC $\{$ lambda $\}$ is associated with enhanced insulin sensitivity and glucose uptake in L6 rat skeletal muscle cells. Am J Physiol Endocrinol Metab. 2010; 299:E402-E412. [PubMed: 20530734]

223. Stuart CA, Howell ME, Zhang Y, Yin D. Insulin-stimulated translocation of glucose transporter (GLUT) 12 parallels that of GLUT4 in normal muscle. J Clin Endocrinol Metab. 2009; 94:35353542. [PubMed: 19549745]

224. Suarez J, Hu Y, Makino A, Fricovsky E, Wang H, Dillmann WH. Alterations in mitochondrial function and cytosolic calcium induced by hyperglycemia are restored by mitochondrial transcription factor A in cardiomyocytes. Am J Physiol Cell Physiol. 2008; 295:C1561-C1568. [PubMed: 19060297] 
225. Sweeney G, Somwar R, Ramlal T, Volchuk A, Ueyama A, Klip A. An inhibitor of p38 mitogenactivated protein kinase prevents insulin-stimulated glucose transport but not glucose transporter translocation in 3T3-L1 adipocytes and L6 myotubes. J Biol Chem. 1999; 274:10071-10078. [PubMed: 10187787]

226. Taegtmeyer H, Overturf ML. Effects of Moderate Hypertension on Cardiac-Function and Metabolism in the Rabbit. Hypertension. 1988; 11:416-426. [PubMed: 3366475]

227. Takeuchi K, McGowan FX Jr, Glynn P, Moran AM, Rader CM, Cao-Danh H, del Nido PJ. Glucose transporter upregulation improves ischemic tolerance in hypertrophied failing heart. Circulation. 1998; 98:II234-II239. discussion II240-II231. [PubMed: 9852908]

228. Tanaka T, Nakatani K, Morioka K, Urakawa H, Maruyama N, Kitagawa N, Katsuki A, ArakiSasaki R, Hori Y, Gabazza EC, Yano Y, Wada H, Nobori T, Sumida Y, Adachi Y. Nitric oxide stimulates glucose transport through insulin-independent GLUT4 translocation in 3T3-L1 adipocytes. Eur J Endocrinol. 3002; 941:76-16.

229. Thong FS, Bilan PJ, Klip A. The Rab GTPase-activating protein AS160 integrates Akt, protein kinase C, and AMP-activated protein kinase signals regulating GLUT4 traffic. Diabetes. 2007; 56:414-423. [PubMed: 17259386]

230. Thorens B, Mueckler M. Glucose transporters in the 21st Century. Am J Physiol Endocrinol Metab. 2010; 298:E141-E145. [PubMed: 20009031]

231. Tian R. Transcriptional regulation of energy substrate metabolism in normal and hypertrophied heart. Curr Hypertens Rep. 2003; 5:454-458. [PubMed: 14594563]

232. Tian R, Abel ED. Responses of GLUT4-deficient hearts to ischemia underscore the importance of glycolysis. Circulation. 2001; 103:2961-2966. [PubMed: 11413087]

233. Tian R, Musi N, D’Agostino J, Hirshman MF, Goodyear LJ. Increased adenosine monophosphate-activated protein kinase activity in rat hearts with pressure-overload hypertrophy. Circulation. 2001; 104:1664-1669. [PubMed: 11581146]

234. Toth PP, Raghavan VA. Glucolipotoxicity and the heart preface. Heart Fail Clin. 2012; 8:XviiXviii. [PubMed: 22999250]

235. Tsao TS, Stenbit AE, Factor SM, Chen W, Rossetti L, Charron MJ. Prevention of insulin resistance and diabetes in mice heterozygous for GLUT4 ablation by transgenic complementation of GLUT4 in skeletal muscle. Diabetes. 1999; 48:775-782. [PubMed: 10102694]

236. Tsunoda N, Maruyama K, Cooke DW, Lane DM, Ezaki O. Localization of exercise- and denervation-responsive elements in the mouse GLUT4 gene. Biochem Bioph Res Co. 2000; 267:744-751.

237. Tsuru M, Katagiri H, Asano T, Yamada T, Ohno S, Ogihara T, Oka Y. Role of PKC isoforms in glucose transport in 3T3-L1 adipocytes: Insignificance of atypical PKC. Am J Physiol Endocrinol Metab. 2002; 283:E338-E345. [PubMed: 12110540]

238. Uhlig M, Passlack W, Eckel J. Functional role of Rab11 in GLUT4 trafficking in cardiomyocytes. Mol Cell Endocrinol. 2005; 235:1-9. [PubMed: 15866422]

239. Uldry M, Ibberson M, Horisberger JD, Chatton JY, Riederer BM, Thorens B. Identification of a mammalian $\mathrm{H}(+)$-myo-inositol symporter expressed predominantly in the brain. EMBO J. 2001; 20:4467-4477. [PubMed: 11500374]

240. Uldry M, Ibberson M, Hosokawa M, Thorens B. GLUT2 is a high affinity glucosamine transporter. Febs Lett. 2002; 524:199-203. [PubMed: 12135767]

241. van der Vusse GJ, Dubelaar ML, Coumans WA, Seymour AM, Clarke SB, Bonen A, DrakeHolland AJ, Noble MI. Metabolic alterations in the chronically denervated dog heart. Cardiovasc Res. 1998; 37:160-170. [PubMed: 9539870]

242. Vettor R, Fabris R, Serra R, Lombardi AM, Tonello C, Granzotto M, Marzolo M, Carruba M, Ricquier D, Federspil G, Nisoli E. Changes in FAT/CD36, UCP2, UCP3 and GLUT4 gene expression during lipid infusion in rat skeletal and heart muscle. Int J Obesity. 2002; 26:838-847.

243. Vinals F, Fandos C, Santalucia T, Ferre J, Testar X, Palacin M, Zorzano A. Myogenesis and MyoD down-regulate Sp1 - a mechanism for the repression of GLUT1 during muscle cell differentiation. J Biol Chem. 1997; 272:12913-12921. [PubMed: 9148896] 
244. Waller AP, George M, Kalyanasundaram A, Kang C, Periasamy M, Hu KL, Lacombe VA. GLUT12 functions as a basal and insulin-independent glucose transporter in the heart. Bba-Mol Basis Dis. 2013; 1832:121-127.

245. Wambolt RB, Henning SL, English DR, Dyachkova Y, Lopaschuk GD, Allard MF. Glucose utilization and glycogen turnover are accelerated in hypertrophied rat hearts during severe lowflow ischemia. J Mol Cell Cardiol. 1999; 31:493-502. [PubMed: 10198181]

246. Wambolt RB, Lopaschuk GD, Brownsey RW, Allard MF. Dichloroacetate improves postischemic function of hypertrophied rat hearts. J Am Coll Cardiol. 2000; 36:1378-1385. [PubMed: 11028498]

247. Wang C, Hu SM. Developmental regulation in the expression of rat-heart glucose transporters. Biochem Bioph Res Co. 1991; 177:1095-1100.

248. Wang D, Pascual JM, Yang H, Engelstad K, Mao X, Cheng J, Yoo J, Noebels JL, De Vivo DC. A mouse model for Glut-1 haploinsufficiency. Hum Mol Genet. 2006; 15:1169-1179. [PubMed: 16497725]

249. Wang ZV, Deng Y, Gao N, Pedrozo Z, Li DL, Morales CR, Criollo A, Luo X, Tan W, Jiang N, Lehrman MA, Rothermel BA, Lee AH, Lavandero S, Mammen PP, Ferdous A, Gillette TG, Scherer PE, Hill JA. Spliced X-box binding protein 1 couples the unfolded protein response to hexosamine biosynthetic pathway. Cell. 2014; 156:1179-1192. [PubMed: 24630721]

250. Watson LJ, Facundo HT, Ngoh GA, Ameen M, Brainard RE, Lemma KM, Long BW, Prabhu SD, Xuan YT, Jones SP. O-linked beta-N-acetylglucosamine transferase is indispensable in the failing heart. P Natl Acad Sci U S A. 2010; 107:17797-17802.

251. Weiss RG, Chatham JC, Georgakopolous D, Charron MJ, Wallimann T, Kay L, Walzel B, Wang Y, Kass DA, Gerstenblith G, Chacko VP. An increase in the myocardial PCr/ATP ratio in GLUT4 null mice. FASEB J. 2002; 16:613-615. [PubMed: 11919171]

252. Wellen KE, Hatzivassiliou G, Sachdeva UM, Bui TV, Cross JR, Thompson CB. ATP-citrate lyase links cellular metabolism to histone acetylation. Science. 2009; 324:1076-1080. [PubMed: 19461003]

253. Wheeler TJ, Fell RD, Hauck MA. Translocation of two glucose transporters in heart: Effects of rotenone, uncouplers, workload, palmitate, insulin and anoxia. Biochim Biophys Acta. 1994; 1196:191-200. [PubMed: 7841183]

254. Willaert A, Khatri S, Callewaert BL, Coucke PJ, Crosby SD, Lee JGH, Davis EC, Shiva S, Tsang M, De Paepe A, Urban Z. GLUT10 is required for the development of the cardiovascular system and the notochord and connects mitochondrial function to TGF signaling. Hum Mol Genet. 2012; 21:1248-1259. [PubMed: 22116938]

255. Winder WW, Hardie DG. Inactivation of acetyl-CoA carboxylase and activation of AMPactivated protein kinase in muscle during exercise. Am J Physiol. 1996; 270:E299-E304. [PubMed: 8779952]

256. Wood IS, Trayhurn P. Glucose transporters (GLUT and SGLT): Expanded families of sugar transport proteins. Br J Nutr. 2003; 89:3-9. [PubMed: 12568659]

257. Wu XH, Freeze HH. GLUT14, a duplicon of GLUT3, is specifically expressed in testis as alternative splice forms. Genomics. 2002; 80:553-557. [PubMed: 12504846]

258. Xing Y, Musi N, Fujii N, Zou L, Luptak I, Hirshman MF, Goodyear LJ, Tian R. Glucose metabolism and energy homeostasis in mouse hearts overexpressing dominant negative alpha2 subunit of AMP-activated protein kinase. J Biol Chem. 2003; 278:28372-28377. [PubMed: 12766162]

259. Yan J, Young ME, Cui L, Lopaschuk GD, Liao R, Tian R. Increased glucose uptake and oxidation in mouse hearts prevent high fatty acid oxidation but cause cardiac dysfunction in dietinduced obesity. Circulation. 2009; 119:2818-2828. [PubMed: 19451348]

260. Yin Z, Haynie J, Yang X, Han B, Kiatchoosakun S, Restivo J, Yuan S, Prabhakar NR, Herrup K, Conlon RA, Hoit BD, Watanabe M, Yang YC. The essential role of Cited2, a negative regulator for HIF-1alpha, in heart development and neurulation. Proc Natl Acad Sci U S A. 2002; 99:10488-10493. [PubMed: 12149478]

261. York JW, Penney DG, Weeks TA, Stagno PA. Lactate-dehydrogenase changes following several cardiac hypertrophic stresses. J Appl Physiol. 1976; 40:923-926. [PubMed: 132420] 
262. Young LH, Renfu Y, Russell R, Hu X, Caplan M, Ren J, Shulman GI, Sinusas AJ. Low-flow ischemia leads to translocation of canine heart GLUT-4 and GLUT-1 glucose transporters to the sarcolemma in vivo. Circulation. 1997; 95:415-422. [PubMed: 9008459]

263. Young ME, Yan J, Razeghi P, Cooksey RC, Guthrie PH, Stepkowski SM, McClain DA, Tian R, Taegtmeyer H. Proposed regulation of gene expression by glucose in rodent heart. Gene Regul Syst Bio. 2007; 1:251-262.

264. Yu J, Auwerx J. The role of sirtuins in the control of metabolic homeostasis. Ann N Y Acad Sci. 2009; 1173(Suppl 1):E10-E19. [PubMed: 19751409]

265. Zachara NE. The roles of O-linked beta-N-acetylglucosamine in cardiovascular physiology and disease. Am J Physiol Heart Circ Physiol. 2012; 302:H1905-H1918. [PubMed: 22287582]

266. Zachara NE, O’Donnell N, Cheung WD, Mercer JJ, Marth JD, Hart GW. Dynamic O-GlcNAc modification of nucleocytoplasmic proteins in response to stress - a survival response of mammalian cells. J Biol Chem. 2004; 279:30133-30142. [PubMed: 15138254]

267. Zaninetti D, Crettaz M, Jeanrenaud B. Dysregulation of glucose-transport in hearts of geneticallyobese (Fa/Fa) rats. Diabetologia. 1983; 25:525-529. [PubMed: 6363180]

268. Zhang J, Duncker DJ, Ya X, Zhang Y, Pavek T, Wei H, Merkle H, Ugurbil K, From AH, Bache RJ. Effect of left ventricular hypertrophy secondary to chronic pressure overload on transmural myocardial 2-deoxyglucose uptake. A 31P NMR spectroscopic study. Circulation. 1995; 92:1274-1283. [PubMed: 7648676]

269. Zhao SM, Xu W, Jiang WQ, Yu W, Lin Y, Zhang TF, Yao J, Zhou L, Zeng YX, Li H, Li YX, Shi J, An WL, Hancock SM, He FC, Qin LX, Chin J, Yang PY, Chen X, Lei QY, Xiong Y, Guan KL. Regulation of cellular metabolism by protein lysine acetylation. Science. 2010; 327:10001004. [PubMed: 20167786]

270. Zhou L, Huang H, Yuan CL, Keung W, Lopaschuk GD, Stanley WC. Metabolic response to an acute jump in cardiac workload: Effects on malonyl-CoA, mechanical efficiency, and fatty acid oxidation. Am J Physiol Heart Circ Physiol. 2008; 294:H954-H960. [PubMed: 18083904]

271. Zimmer HG. Regulation of and intervention into the oxidative pentose phosphate pathway and adenine nucleotide metabolism in the heart. Mol Cell Biochem. 1996; 161:101-109. [PubMed: 8901462]

272. Zimmer HG, Ibel H, Steinkopff G. Studies on the hexose monophosphate shunt in the myocardium during development of hypertrophy. Adv Myocardiol. 1980; 1:487-492. [PubMed: 6156478] 


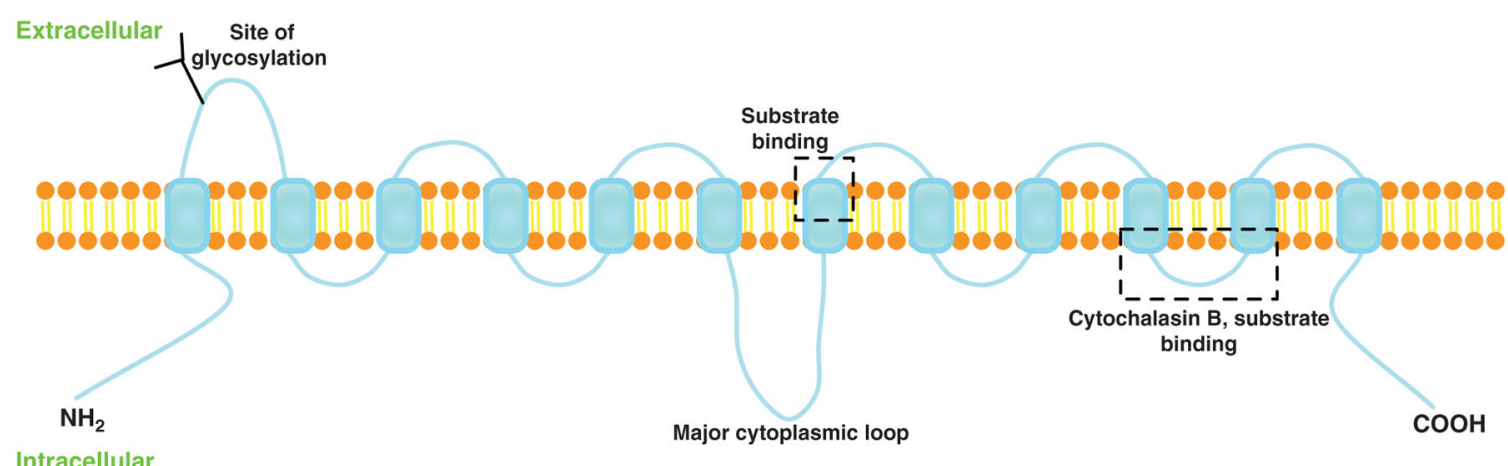

Figure 1.

Schematic model of GLUTs in the plasma membrane with 12 membrane-spanning domains and 6 exofacial loops. The proposed substrate or cytochalasin B-binding site, and the Nlinked glycosylation site are indicated. 


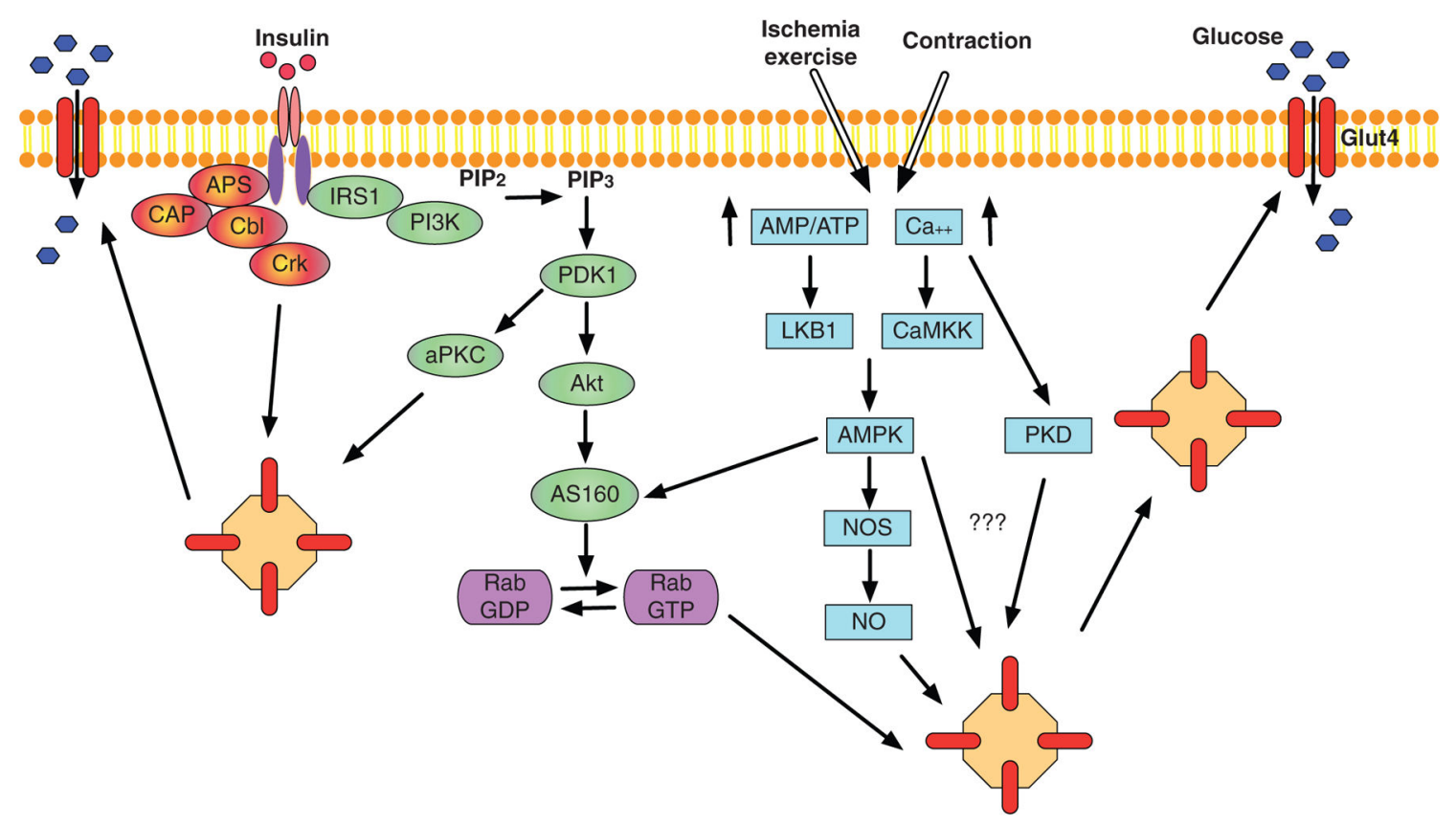

Figure 2.

Major signaling mechanisms mediating GLUT4 translocation in muscle and/or adipose tissues: insulin (red and green), ischemia/exercise or contraction (blue) stimulated GLUT4 translocation. For insulin signaling cascade, PI3-kinase-dependent (green) and independent (red) pathways are described. APS, adapter protein with Pleckstrin homology and Src homology 2 domains; CAP, c-Cbl-associated protein; Cbl, Casitas B-lineage Lymphoma; Crk, v-crk avian sarcoma virus CT10 oncogene homolog; IRS1, Insulin receptor substrate 1; PI3K, phosphoinositide 3-kinase; PIP2, phosphatidylinositol 4,5-bisphosphate; PIP3, phosphatidylinositol 3,4,5-triphosphate; PDK1, 3-phosphoinositide dependent protein kinase-1; Protein kinase B, Akt; AS160, Akt substrate of $160 \mathrm{kDa}$; aPKC, atypical protein kinase C; LKB1, liver kinase B1; CaMKK, calcium/calmodulin-dependent protein kinase kinase; AMPK, 5' AMP-activated protein kinase; PKD, protein kinase D; NOS, nitric oxide synthase; NO, nitric oxide. 


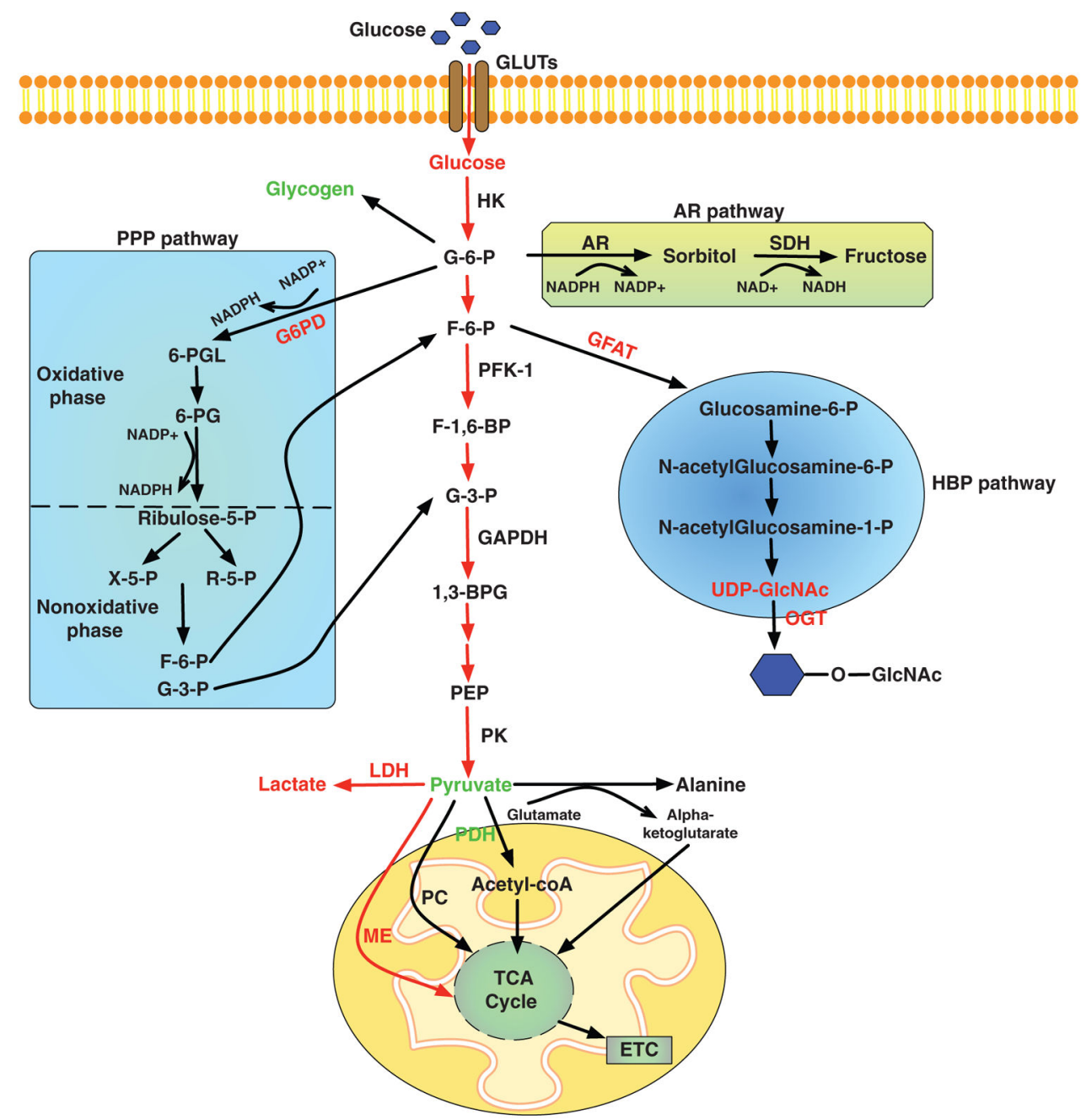

Figure 3.

Glucose metabolism pathways in the heart. Changes in the levels of metabolites, key enzymes, or fluxes during pathological cardiac hypertrophy are shown in red (increased) or green (unaltered). G6PD, glucose-6-phosphate dehydrogenase; 6-PGL, 6-

phosphogluconolactone; 6-PG, 6-phosphogluconate; NADP+, nicotinamide adenine dinucleotide phosphate; NADPH, reduced nicotinamide adenine dinucleotide phosphate; X-5-P, xylose-5-phosphate; R-5-P, ribose-5-phosphate; AR, aldose reductase; SDH, sorbitol dehydrogenase; NAD+, nicotinamide adenine dinucleotide; NADH, reduced nicotinamide adenine dinucleotide; HK, hexokinase; G-6-P, glucose-6-phosphate; F-6-P, fructose-6phosphate; PFK-1, phosphofructokinase-1; F-1,6-BP, fructose-1,6-bisphosphate; G-3-P, glyceraldehyde 3-phosphate; 1, 3-BPG, 1,3-diphosphoglycerate; GAPDH, glyceraldehyde-3-phosphate dehydrogenase; PEP, phosphoenolpyruvate; PK, pyruvate kinase; $\mathrm{LDH}$, lactate dehydrogenase; $\mathrm{PDH}$, pyruvate dehydrogenase; acetyl-coA, acetyl coenzyme A; PC, pyruvate carboxylase; ME, malic enzyme; TCA, tricarboxylic acid; ETC, electron transport chain; GFAT, glutamine fructose-6-phosphate aminotransferase; UDPGlcNAc, uridine diphosphate-N-acetylglucosamine; OGT, O-GlcNAc transferase. 


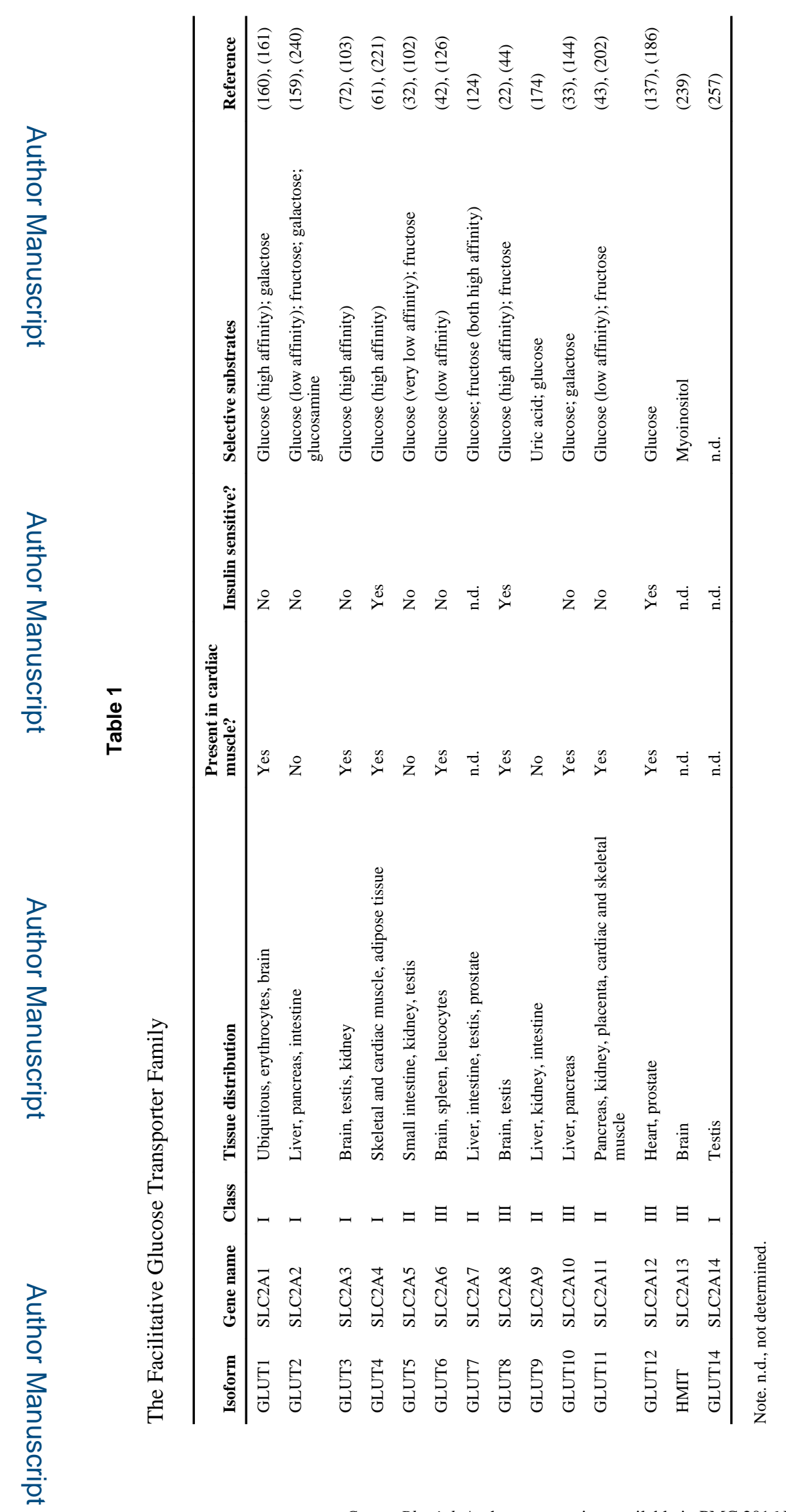

Compr Physiol. Author manuscript; available in PMC 2016 February 19. 


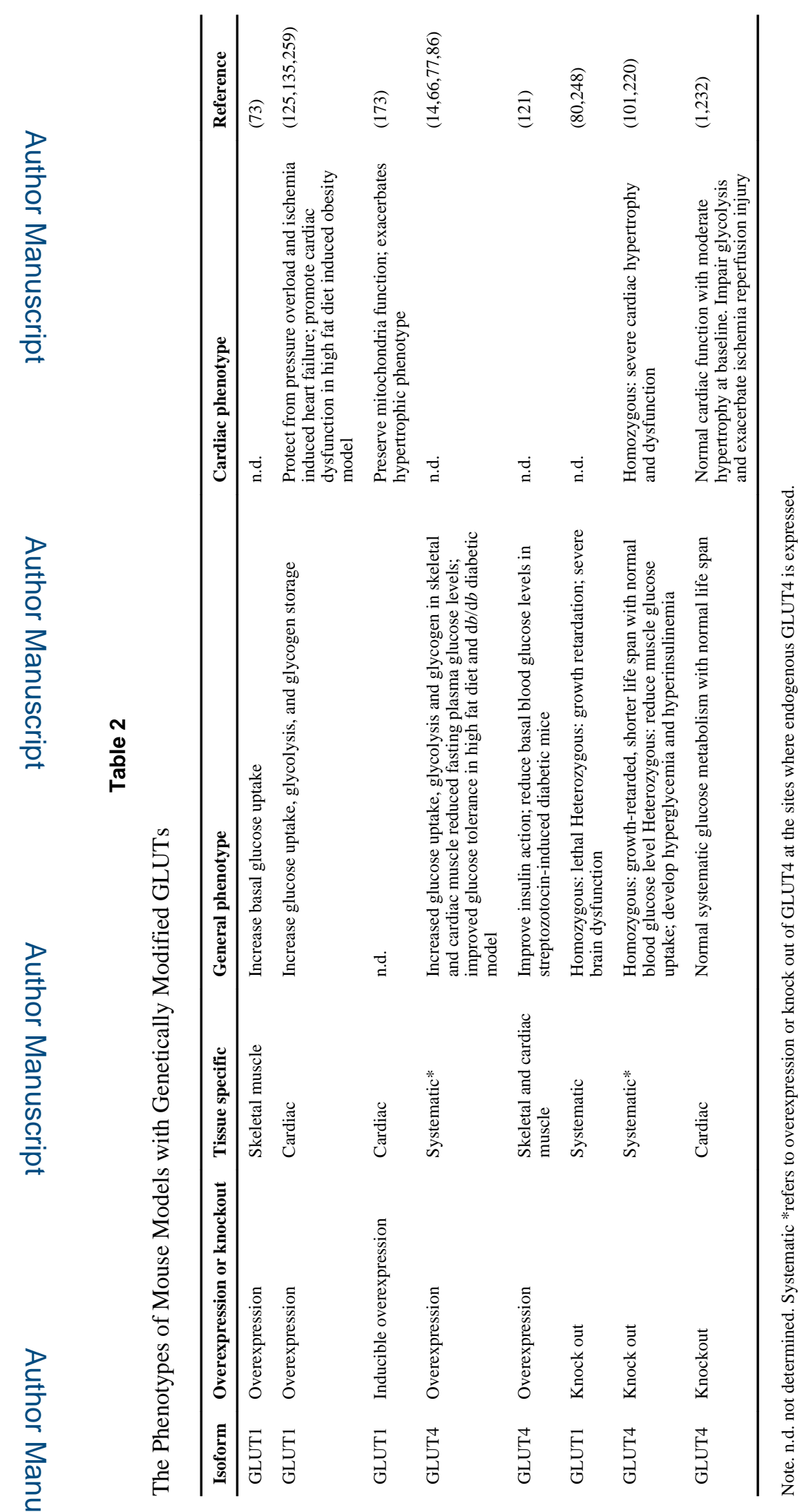

Compr Physiol. Author manuscript; available in PMC 2016 February 19. 